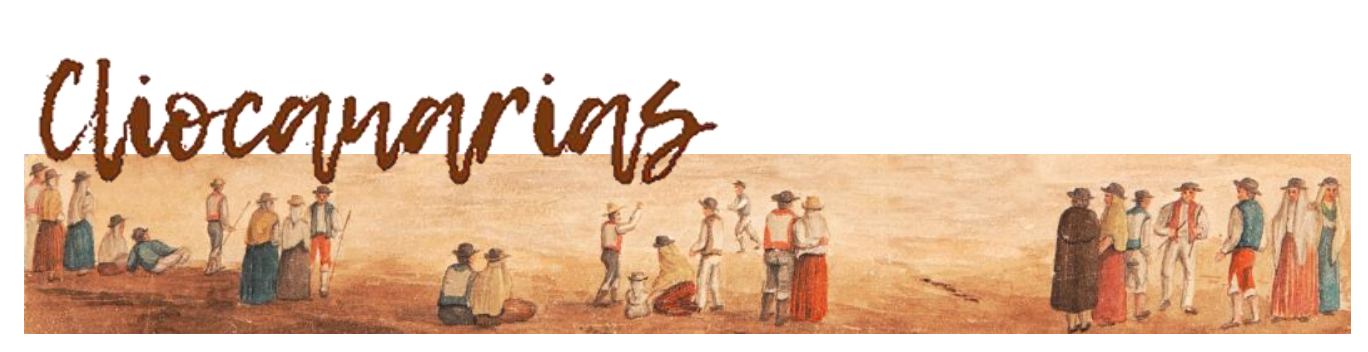

ISSN 2695-4494

https:/ / doi.org/ 10.53335/cliocanarias.2021.3.10

\title{
LA EXPANSIÓN DE LA BANCA Y EL COMERCIO GENOVÉS EN LOS SIGLOS XVI Y XVII. LA PRESENCIA DE LOS VIVALDO EN LA MONARQUÍA HISPÁNICA
}

\author{
THE EXPANSION OF GENOESE BANKING AND COMMERCE IN THE 16TH AND 17TH \\ CENTURIES. THE PRESENCE OF THE VIVALDO IN THE \\ HISPANIC MONARCHY
}

Mercedes GÓMEZ OREÑA*

RESUMEN: El espíritu comercial de los grandes linajes nobiliarios genoveses les permitió constituirse en uno de los grupos más importantes y dinámicos del entramado mercantil y financiero de la Corona española durante los siglos XVI y XVII. Los Vivaldo serán una de estas familias, cuyas actividades económicas estarán muy diversificadas, siendo, entre otros, los negocios en torno a las rentas eclesiales los que les proporcionarán un gran impulso, aunque será también el detonante de su caída.

PALABRAS ClAVE: finanzas, Corona, Iglesia, comercio y linaje.

ABSTRACT: The commercial spirit of the great Genoese noble lineages allowed them to become one of the most important and dynamic groups in the commercial and financial network of the Spanish Crown during the 16th and 17th centuries. The Vivaldos will be one of these families, whose economic activities will be highly diversified, being, among others, the businesses around ecclesial income that will provide a great boost, although it will also be the trigger for their downfall.

KEYwORDS: finance, Crown, Church, commerce and lineage.

\section{Introducción}

El estudio de las casas mercantiles genovesas ha suscitado en las últimas décadas un gran interés por parte de la historiografia, entre otras cuestiones, por la estrecha vinculación que tenían con la monarquía hispánica, para la que se constituyeron como banqueros reales ${ }^{1}$. Será en el siglo XIII, en un contexto de rivalidad con los venecianos por el control de las rutas comerciales

\footnotetext{
* Doctora en Historia. Profesora de educación secundaria. C. e.: mercedes.gomezorena@educa.madrid.org
} 
del Mediterráneo oriental y de los mares Negro y Azov, cuando inicien su andadura comercial en tierras españolas. Entre los primeros en llegar a este territorio se encontraban los hermanos Bonavia, Pagan y Jácome Vivaldo, quienes se establecieron en Sevilla, donde sus actividades comerciales les reportaron importantes beneficios, parte de los cuales sirvieron para la adquisición de inmuebles en esta ciudad y en el Puerto de Santa Maria ${ }^{2}$. Quizás la atracción por este último enclave vino definida por ser un lugar propicio desde donde partir para explorar las costas africanas más allá de las Columnas de Hércules. Este interés por sondearlas estaría relacionado con una nueva ruta para llegar a las Indias o para comerciar con el oro, la pimienta, el marfil y los esclavos que se explotaban en África. Siguiendo estos propósitos, los hermanos Ugolino y Vadino Vivaldo iniciaron este periplo en 1291 acompañados por Teodosio Doria, dos franciscanos y la pertinente tripulación. Partieron en dos galeras con rumbo hacía el estrecho de Gibraltar, aunque no se tiene constancia segura de su itinerario, pues las noticias de esta travesía no quedan aclaradas en los anales históricos. Algunas crónicas apuntan que una tempestad destruyó las naves cuando arribaron a las islas Canarias; otras señalan que fueron capturados; un códice genovés asegura que llegaron a Senegal, donde fueron hechos prisioneros y de alli trasladados a Abisinia, e, incluso, un texto español establece la ciudad concreta a la que fueron trasferidos, Aksum, mientras que otras fuentes van más allá, situándolos en la India, última meta de estos expedicionarios ${ }^{3}$.

Fuera como fuese, lo cierto es que los Vivaldo mantuvieron una importante actividad mercantil, que se orientará más exclusivamente hacía la península ibérica como consecuencia de tres importantes acontecimientos: la caída de Constantinopla por los turcos en 1453, evento que cerraba las rutas hacía Oriente; la conclusión de la Reconquista por los Reyes Católicos, que proporcionaba la estabilidad politica necesaria para un buen desarrollo del comercio, y el descubrimiento de América en 1492, que abria un nuevo mercado donde operar. Durante cuatro centurias tendrá esta familia intereses comerciales en diferentes ciudades de España, siendo las principales Sevilla - lugar desde donde partían hacia América las flotas y galeones-, Medina del Campo - por

\footnotetext{
1 Véase entre otros: SANZ AYÁN, Carmen: Los banqueros de Carlos II, Universidad de Valladolid, 1988; ibid.: Un banquero en el siglo de Oro. Octavio Centurión, el financiero de los Austrias, La Esfera de los Libros, Madrid, 2015; ÁLVAREZ NOGAL, Carlos: "Los banqueros de Felipe IV y los metales preciosos americanos (1621-1665)", Estudios de Historia Económica, n. ${ }^{\circ} 36,1997$; "Las compañias bancarias genovesas en Madrid a comienzos del siglo XVII", Hispania, vol. 65, n. ${ }^{\circ}$ 219, 2005, y El Crédito de la Monarquía Hispánica en el Reinado de Felipe IV, Ávila, Junta de Castilla León, 1997; HERRERO SÁNCHEZ, Manuel (Coord.): Génova y la Monarquía Hispánica (1528-1713), Società Ligure di Storia Patria, Génova, 2011, y «La quiebra del sistema hispano-genovés (1627-1700)", Hispania, n. ${ }^{\circ} 219,2005$.

2 Sobre ellos véase JIMÉNEZ LÓPEZ DE EGUILETA, Javier: "Micer Bonavía de Vivaldo, alcaide de El Puerto de Santa María, y los orígenes del latifundismo en la baja Andalucía (siglos XIII y XIV)", Revista de Historia de El Puerto, n. ${ }^{\circ}$ 60, 2018 (1 ${ }^{\text {er }}$ semestre), pp. 133-147.

3 Sobre la expedición de los Vivaldo véase, entre otros, QUARTAPELLE, Alberto: "El "loco vuelo" de los hermanos Vivaldi en 1291", Revista de Historia Canaria, n. ${ }^{\circ}$ 200, 2018, pp. 227249; GILLIAM, Moore: "La spedizione dei fratelli Vivaldo e nuovi documenti d'archivio", Atti della Società Ligure di Storia Patria, n. s., 12/2, 1972, pp. 387-402, y MADAO, Matteo: Dissertazioni Storiche Apologetiche Critiche delle Sarde Antichità, Cagliari, nella Reale Stamperia, tomo I, Cagliari, 1792, pp. XXIII-XIV.
} 
ser centro ferial y cambista de magnitud internacional-, y Madrid, al albergar a las altas esferas politicas tras el establecimiento definitivo de la Corte. Será en esta última donde a finales del siglo XVII concluya esta estirpe las operaciones económicas que venían realizando como consecuencia de la bancarrota sufrida por uno de sus miembros, Juan Bautista Cassani Vivaldo, personaje que ha sido el principio rector de este estudio ${ }^{4}$.

\section{Los origenes}

El linaje de los Vivaldo, también conocidos como Vivaldi ${ }^{5}$, saga de militares, políticos y mercaderes, se localiza en las ciudades ligures de Taggia y Génova. Para su estudio hemos seguido la linea de tres autores: De Rivarola y Pineda, Madao y Battilana ${ }^{6}$, si bien solo señalan a los miembros cuya nobleza ha quedado demostrada por haber ostentado cargos políticos dentro de la República genovesa, quedando fuera de ellos los que se emparentaron con casas de un estatus social inferior y los que salieron al exterior a negociar. Los dos últimos sitúan el tronco primigenio en los inicios del s. XII con Guglielmo Vivaldi, cuya sustancial fortuna y distinción le permitió acceder a los cargos de consejero y gobernador de su patria en cuatro ocasiones. Su sucesor Robaldo armó de su propio bolsillo un regimiento para socorrer al duque de Borgoña. En la guerra sobresalió también Lupo Vivaldi, señor de Taggia, famoso por ser el terror de los enemigos de su tierra y por servir al rey Carlos II de Nápoles, quien le nombró su chambelán en 1300. El enfrentamiento entre los partidarios del papa, güelfos, y los del emperador, gibelinos, sitúo a Oberto y Manfredo Vivaldi en el bando de los segundos, prestando ayuda militar al emperador Ludovico de Baviera en los años 1319 y 1329. La actividad bélica de los Vivaldo continuó a lo largo de los siglos XIV, XV y XVI, lo que les posibilitó alcanzar los más altos grados militares. Uno de ellos, Felipe, capitaneó en 1423 las naves que lucharon contra Alfonso V de Aragón, mientras que Bartolomé en 1426 comandó los barcos que el mismo armó para enfrentarse a los güelfos florentinos. Asimismo, Tomaso, Enmanuel y Benedicto Vivaldo combatieron bajo las órdenes del célebre capitán Rafael Doria.

Al tiempo que una parte de los miembros de la familia participaba en acciones castrenses, otros fueron comisionados como plenipotenciarios para negociar en las Cortes europeas. Las embajadas más distinguidas fueron las expedidas al imperio y el papado. Al primero asistieron en dos ocasiones: una estando Federico III al frente del mismo, la otra siendo Carlos V su titular. En cambio, al segundo acudieron en cinco ocasiones, donde se entrevistaron con los siguientes pontífices: Inocencio VII, Nicolás V, Julio II, León X y Pablo III.

\footnotetext{
4 Sobre este personaje véase GOMEZ OREÑA, Mercedes: Juan Bautista Cassani. Un banquero genovés en la España del siglo XVII, Editorial Académica Española, 2018.

5 En la documentación algunos miembros de esta familia vienen señalados indistintamente como Vivaldo o Vivaldi. Los nombres también aparecen en italiano o castellano en función de las fuentes consultadas, de ahí que en este trabajo sean mencionados de ambas formas.

${ }^{6}$ DE RIVAROLA Y PINEDA, Juan Félix Francisco: Historia Chronológica y Genealógica, civil, politica, y militar de la Serenissima República de Génova, Diego Martín Abad, Madrid, 1729, p. 419; MADAO, Matteo: Dissertazione..., op. cit., pp. XXII y XXIII, y BATTILANA, Natale: Genealogie delle famiglie nobili di Genova, Dalla Tipografia dei Fratelli Pagano, Genova, 1825.
} 
También visitaron Francia, Portugal, Aragón, Nápoles, Milán, Florencia y Venecia ${ }^{7}$. Además, defendieron los intereses comerciales ligures ejerciendo como cónsules en ciudades en torno a los mares Negro, Azov y Mediterráneo, siendo las más significativas las de Caffa de Crimea, Trebisonda, Nicosia, Cataluña, Sicilia y Tana. En esta última nos consta que en 1429 estuvo Andreolo Vivaldo.

A partir de la reforma politica llevada a cabo en Génova en 1528, para acceder a las magistraturas y, por ende, al poder politico era imprescindible pertenecer a uno de los veintiocho alberghi o casas nobiliarias, las cuales se clasificaban en cuatro grupos según el número de integrantes que las conformaban y su peso económico. En la cima de todos ellos se hallaban cuatro estirpes principales: los Doria, Spinola, Fieschi y Grimaldi. Tras ellas, otras cinco grandes familias: los Cattaneo, Gentile, Lomellini, Salvago y Pinelli. De una importancia menor: los Centurión, Grillo, Imperial, Italiano, Lercari, Marini, Negro, Cibo, Vivaldo y Negroni. Por último, con significación más limitada los linajes de los Mari, Calvi, Cigala, Camilla, Pallavicino, Squarzafigo, Usodimare, Serra y Colonne, etc. ${ }^{8}$. Pese a estar en un escalón intermedio, los Vivaldo incrementaron su notoriedad a través de los enlaces matrimoniales llevados a cabo con las casas más distinguidas: Spinola, Doria, Fieschi, Lomellino y Gentile. Esto se tradujo en un mayor peso politico y ser inscritos en el gran libro de oro de la nobleza genovesa donde, según Madao, aparecen señalados desde 1152 hasta 1477 veintisiete ancianos nobles purpurados de esta estirpe. Entre 1375 y 1461 serán dieciocho los consejeros, siendo Percivale uno de los más reconocidos, no solo por la defensa de los intereses de la Liguria, especialmente significativos en Cataluña y Sicilia, sino por ser uno de los impulsores, tras su nombramiento en 1413, del establecimiento de un nuevo reglamento del Estado y de la gran reforma de las leyes concernientes a la elección de dogo o dux. Desde 1577 hasta 1646 se registraron ocho senadores; entre los más estimados se encontraban: Jácome, que accedió al cargo en 1577; Andrea, que lo hizo en 1581; Giovanni Battista, en 1590; y Girolamo en tres ocasiones (1628, 1640 y 1646). Asimismo ejercieron como gobernadores y capitanes de Chiavari, ciudad del golfo ligur, donde sobresalieron en 1565 y 1600 Jácome y Lelia, respectivamente. Pero, sin lugar a dudas, el miembro más notorio de este linaje fue Girolamo Vivaldo, que el 4 de enero de 1559 fue nombrado dux 9 . La politica conyugal la llevaron a cabo también con otras familias genovesas, como los Di Negro, Imperiale, Grillo, Franchi, Pascua, Federici, e incluso con las de otras regiones de Italia: los Rivarola de Parma; los Spada, originarios de Luca; los Giudice, genoveses asentados en Nápoles; los Alfaroli, de Pistoia; los Massa y Orsini, de Roma, o los Castelvi-Aymerich, de Cerdeña ${ }^{10}$. De estas uniones surgieron diferentes ramas que se fueron extendieron fuera de la Liguria y traspasaron incluso los territorios italianos.

\footnotetext{
7 Existe una larga nómina de las embajadas de los Vivaldo en el exterior (Ibid., pp. XXIV y XXV).

8 GRENDI, Edoardo: "Profilo storico degli alberghi genovesi», Mélanges de l'école française de Rome, n. ${ }^{\circ}$ 87-1, 1975, pp. 241-302.

9 MADAO, Matteo: Dissertazione..., op. cit., pp. XXIV-XXV. También los cargos desempeñados por algunos de los personajes citados los hemos tomado de RIVAROLA Y PINEDA DE, Juan Félix Francisco: Historia Chronológica..., op. cit., p. 419.

10 MADAO, Matteo: Dissertazione..., op. cit., pp. XXVII y XXVIII; y RIVAROLA Y PINEDA DE, Juan Félix Francisco: Historia Chronológica... op. cit., p. 419.
} 
La nobleza quedaba subrayada en el escudo de armas, cuyos símbolos se elegían cuidadosamente. El de esta familia presentaba en su parte superior o jefe un águila negra coronada con las alas extendidas dispuesta al vuelo, que personificaba el poder y la heroicidad. Bajo ella dos campos, uno púrpura y otro de oro, aunque según Battilana era de plata, que simbolizaba la nobleza y la riqueza. Sobre él, una corona de siete puntas que aludía a la vida eterna y la perfección.

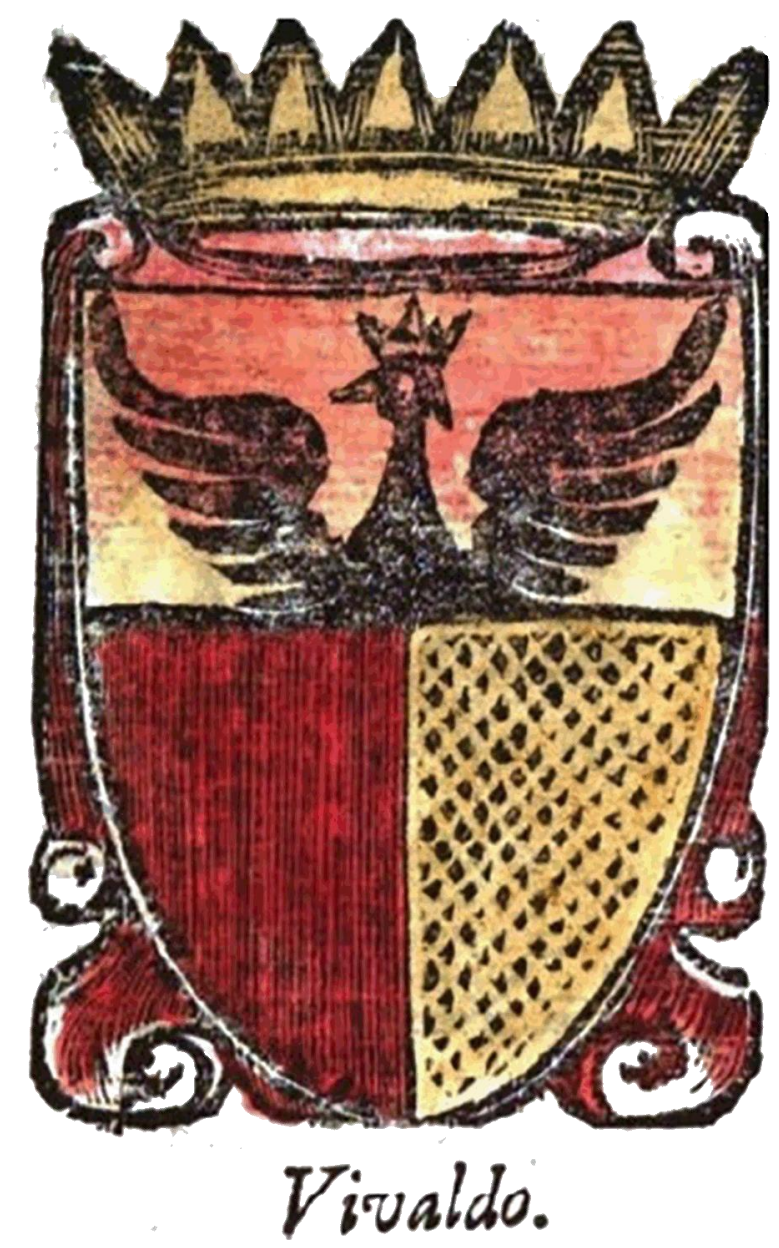

Figura 1. Escudo de los Vivaldo ${ }^{11}$

Esta estirpe no solo aspiró a alcanzar un estatus elevado en su tierra natal; también lo persiguió fuera de ella, como podemos constatar por la demanda judicial presentada en 1523 por Agustín y Adán Vivaldo en la sala de Hidalguía de la Real Chancillería de Valladolid, pleito que concluyó favorablemente en la de Granada ${ }^{12}$. El ser poseedor de esa estimación suponía una serie de beneficios, entre los que se encontraba la obtención de hábitos militares, adquisición de títulos nobiliarios, acceso a altos cargos del estamento religioso e, incluso, estar exento del pago de determinados tributos. En cuanto a los primeros, la documentación consultada nos reporta algunos ejemplos, como el de los hermanos Juan Vicencio y Juan Tomás Vivaldo y Valdetaro, que ingresaron en la

11 Tomado de RIVAROLA Y PINEDA DE, Juan Félix Francisco: Historia Chronológica..., op. cit., p. 274.

12 Archivo de la Real Chancillería de Valladolid (ARCV), Sala de Hijosdalgo, Caja 1404, 4; Registro de Ejecutorias, leg. 0134, 141-149; leg. 0156 y leg. 0206. 
orden de Santiago en 1623 y 1626, respectivamente, y el de Juan Esteban Vivaldo de Canevaro en 1649. En la de Calatrava lo obtuvieron en 1667 Luis de Castillo y Cervino Carrillo Vivaldo, y en 1640 Vicente y Juan, hijos de Rolando Levanto y María Vivaldo. Otros dos vástagos de este matrimonio, Pedro Francisco y Juan Francisco, hicieron carrera en el seno de la Iglesia, el primero como capellán real y el segundo como obispo de Badajoz ${ }^{13}$. En relación con los títulos nobiliarios tenemos el caso de Juan Francisco Pascua Vivaldo, que adquirió el marquesado de Treviño el 2 de mayo de 1662. En cuanto a las prerrogativas fiscales, queda patente en la rama de la familia que se avecinaron en Sevilla, quienes nada más adquirir el estatus de hidalguía no solo tomaron el "de" como apellido, sino que solicitaron la exención del tributo que se cargaba sobre la carne, impuesto conocido como la blanca de la carne ${ }^{14}$.

Los Vivaldo, además de participar activamente en la vida política y militar de su tierra natal, fueron grandes comerciantes, especialmente dinámicos en el entramado financiero de la monarquía hispánica durante los siglos XVI y XVII. La relación de parentesco de los miembros de la Liguria con los que se establecieron en la península ibérica ha sido difícil de establecer. Tampoco ha resultado fácil determinar la conexión existente entre estos últimos, si bien creemos que pertenecian a la misma linea a tenor de los negocios que mantuvieron en torno a la tesorería de la Cámara Apostólica, a la que estuvieron ligados desde 1505 hasta 1684 por el asentamiento de algunos familiares directos en Roma. Según Battilana y Madao, descendian del legislador Percivale Vivaldo. El primero realizó un árbol genealógico de todas las ramas Vivaldo (una de ellas es la que presentamos a continuación), mientras que el segundo solo cita a los integrantes más distinguidos del ámbito político, que nominaremos después.

A Percivale le sigue en la línea sucesoria Giovanni I. Tras él, Ludovico, que contrajo matrimonio con la noble Giulia Fieschi Costa, de cuyo enlace nació Agostino, padre de Girolamo II, el ya mencionado dux. Su hijo, Giovanni Battista, aunque no alcanzó esta dignidad, sí obtuvo la de senador. De su matrimonio con Maria Curlo nacieron cinco hijos: Vicenza, Pietro Maria, Vicenzo, Girolamo III y Gironima. Por documentos notariales conocemos que el mayor de los hermanos varones estuvo al frente de la casa Vivaldo en Madrid, mientras que del segundo no tenemos ninguna referencia, pues Madao solo cita a Girolamo, porque accedió a las magistraturas del Estado. Desempeñó en tres ocasiones el cargo senatorial, por lo que fue inscrito en el libro de la nobleza,

\footnotetext{
13 Archivo Histórico Nacional (AHN), Órdenes Militares, Caballeros de Santiago, Expediente, p. 8.993, año 1623, y Expedientillos n. ${ }^{\circ} 1.128$, año 1626; Biblioteca de la Real Academia de la Historia (BRAH), Colección Salazar, sig. M-34, 50.761 (6) f. ${ }^{\circ} 29$. Véase también MOGROBEJO, Endika, Irantzu y Garikoitz: Diccionario Hispanoamericano de Heráldica, Onomástica y Genealogía, Editorial Mogrobejo-Zabala, Bilbao, 1995; FERNÁNDEZ-MOTA DE CIFUENTES, Maria Teresa: Relación de Títulos Nobiliarios Vacantes, y Principales Documentos que contiene cada expediente que, de los mismos, se conservan en el Archivo del Ministerio de Justicia, Instituto Salazar y Castro, Hidalguía, $2 .^{a}$ edición, Madrid, 1984; y MADAO, Matteo: Dissertazione..., op. cit., p. 30.

${ }^{14}$ DÍAZ DE NORIEGA Y PUBUL, José: La Blanca de la carne en Sevilla, Hidalguía, tomo I, II, y IV, Madrid, 1977.
} 
como establecían los órganos de gobierno de la república: el dux, el consejo de cientos y los colegios de senadores y procuradores ${ }^{15}$.

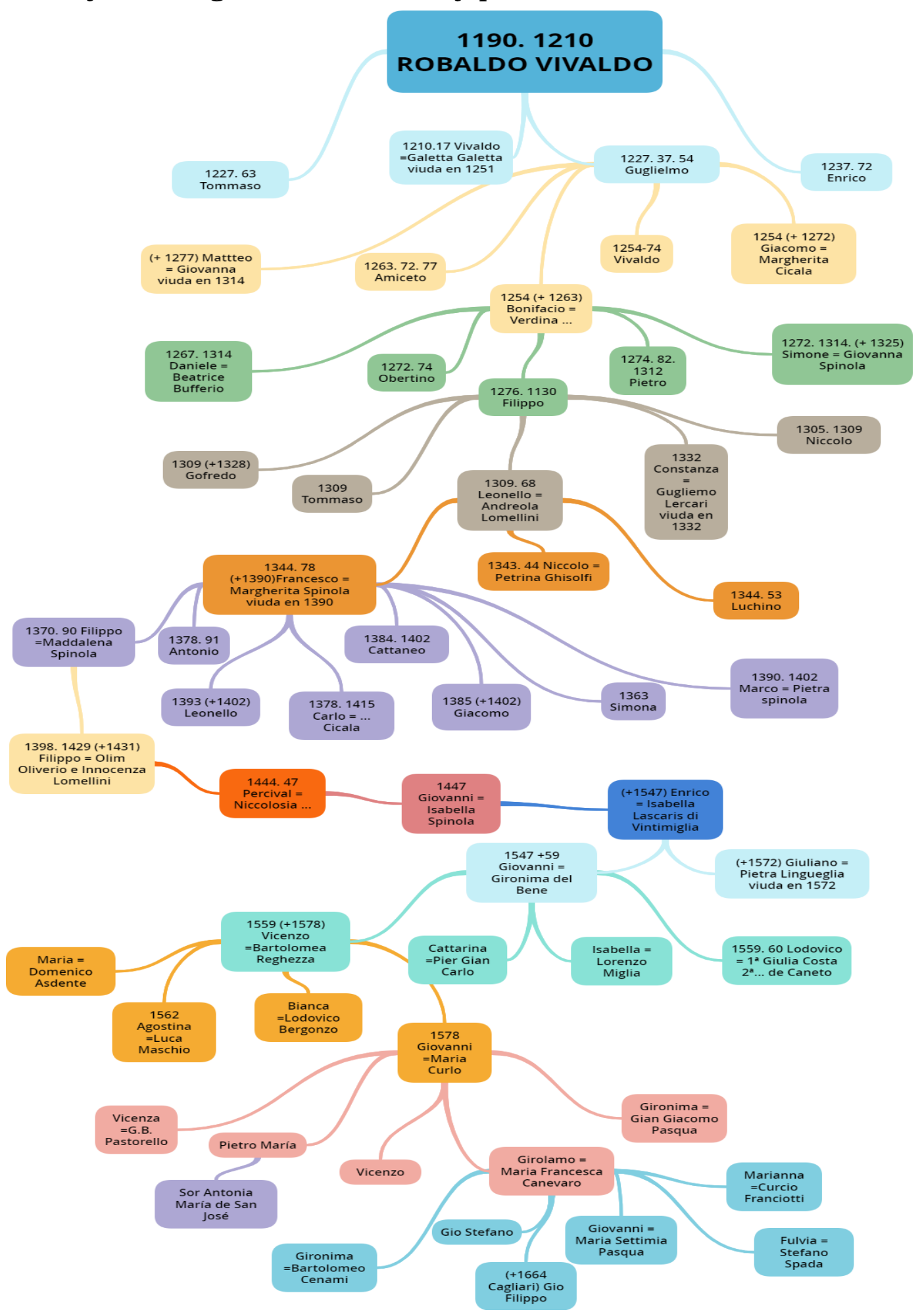

Figura 2. Genealogía de los Vivaldo ${ }^{16}$

15 RIVAROLA Y PINEDA DE, Juan Félix Francisco: Historia Chronológica..., op. cit., p. 274. 16 Elaboración propia con los datos de BATTILANA, Natale: Genealogie..., op. cit. Hemos tomado la información de la hija de Pedro María del Archivo de Protocolos Notariales de Madrid (AHPNM), p. ${ }^{\circ}$ 6.241, fols. 911-916 r. 
Girolamo contrajo matrimonio con Maria Francesca de Canevaro Giustiniani, con la que tuvo seis hijos: Gironima, Gio Stefano, Gio Filippo, Giovanni, Marianna y Fulvia. El primero de los hombres logró un ascendente significativo dentro de la banca romana, a donde se trasladó la familia, lo que le permitió ser reconocido como caballero de la orden de San Giacomo. A este privilegio añadió el hábito de Santiago, que obtuvo en 1649 cuando se trasladó a Madrid para hacerse cargo, en nombre de su padre, de la herencia de su tío Pietro Maria, que habia fallecido sin descendencia masculina. El segundo alcanzó el estatus de noble patricio romano al ser nombrado magistrado capitolino del Senado y cabecilla del distrito de los Colonna, mientras que el último ingresó en la abadía benedictina de Santa Elena en Pantasia, donde fue abad comendatario y prelado mitrado ${ }^{17}$.

La muerte del mencionado Pietro Maria obligó a realizar ajustes en la administración de los negocios de Madrid, que quedaron a cargo de Juan Francisco Pascua, hijo de Giromina, hermana del difunto. Sin embargo, el deceso de Gio Stefano en Roma en torno a 1657 y de Gio Filippo en Cagliari en 1664 forzaría a salir del convento a Giovanni para hacerse cargo del importante patrimonio familiar, que incrementaría dos años más tarde al unirse en matrimonio con Settimia Gerolama Pascua Di Negro, única hija de su primo Juan Francisco. Este último, que obtuvo en 1662 el privilegio del marquesado de Treviño, agasajó a la pareja con la cesión del título, que unirian al de barón de las Tres Tierras del convento de Santa Elena, Montecalvo y Tonnicchio ${ }^{18}$.

Antes de dejar Juan Francisco Pascua la compañia madrileña estuvo preparando durante dos años seguidos al nuevo administrador de la misma, su otro primo Juan Bautista Cassani Vivaldo, quien se hará cargo de la misma hasta 1684, fecha en la que se produjo la bancarrota de la casa y con la que concluirá la actividad comercial y financiera de esta rama Vivaldo en España. Este último era hijo de Juan María Cassani y Benedicta Vivaldo, y aunque el parentesco directo de la madre con esta saga no lo hemos podido determinar, creemos - pese a que Battilana no lo señala- que era hermana de Girolamo y Pietro Maria, pues en algunos documentos notariales Juan Bautista Cassani los señala como sus tíos, y a los hijos del primero como sus primos. Nos consta que el matrimonio también se trasladó a Roma, donde nacieron sus cinco hijos: el citado Juan Bautista, Domingo Maria, Marcos, Francisca y Ana Teresa. Los varones se educaron en el colegio jesuita romano, ingresando una vez concluida su formación académica en la compañia familiar para instruirse en los negocios. Si la necesidad obligaba, debían trasladarse a una filial foránea para concluir su aprendizaje. A veces, dicho desplazamiento podía constituirse en permanente. Así fue el de Juan Bautista cuando vino a Madrid o el de Domingo María cuando se afincó en Amberes, por lo que ambos constituyeron su propia familia en sendas ciudades. El primero se casó con Francisca Antonia Fernández de Merodio, con la que tuvo siete hijos, y el segundo con Teresa Torgat, con la que tuvo cinco. Por el contrario, Marcos, después de

17 DOMINICIS DE, CLAUDIO: Membri del Senato della Roma Pontificia. Senatori, Conservatori, Caporioni e loro priori e lista d'oro delle famiglie dirigente (secc. X-XIX), Roma, Fondazione Marco Besso, 2009.

18 MADAO, Matteo: Dissertazione..., op. cit., pp. XXX. 
pasar un tiempo en Madrid, regresó nuevamente a Roma. En un principio, creemos, su estancia iba a ser duradera, pues se prometió por escrito con Antonia Cassares, aunque se retractó poco después ${ }^{19}$. En cuanto a las dos hermanas, Francisca formó parte del negocio familiar a través de su matrimonio con el financiero romano Carlos Ghirlandari, con el que tuvo tres hijos, mientras que Teresa ingresó en el monasterio de Santa Margarita del Trastévere de Roma.

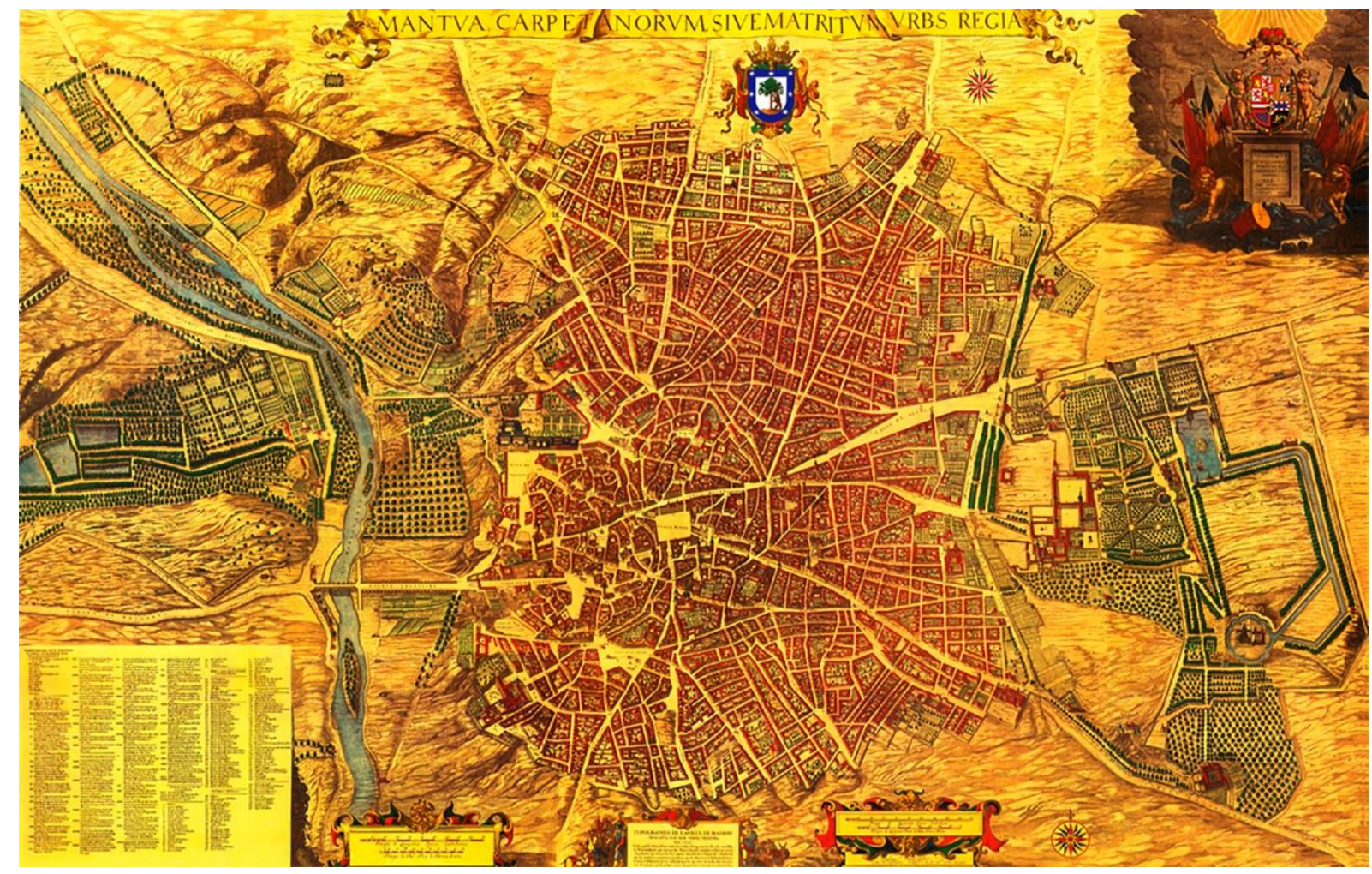

Figura 3. Plano de Madrid en 1656, realizado por Pedro Teixeira. (Imagen de dominio público)

Los Vivaldo afincados en España mantuvieron siempre un estrecho vínculo con su tierra natal; de hecho, algunos miembros en sus testamentos tuvieron presentes a sus antepasados asignando ciertas cantidades de numerario a la capilla que poseían en el convento de Santo Domingo de Taggia ${ }^{20}$. También recurrieron a los enlaces matrimoniales con sus compatriotas, aunque por cuestiones de negocio lo hicieron también con los naturales del territorio donde se asentaron. Realizarán uno u otro enlace y su lugar de residencia lo establecían junto a sus paisanos formando colonias. En Madrid se localizaba en el conocido barrio de las Letras, donde se agrupaban también escritores y actores de teatro, lo que favorecia unas relaciones intensas entre estas colectividades. Posiblemente el vínculo de los Vivaldo y Miguel de Cervantes naciera de ese contexto social. Según Juan Bautista Avalle-Arce, la amistad que hubo entre

19 Archivo Histórico de Protocolos Notariales de Madrid (AHPNM), leg. 11.447, fols. 823-824v. Para evitar una demanda judicial tuvo que desembolsar una importante cantidad que serviría para engrosar la dote de la afectada.

20 AHPNM, leg. 6.241, fols. 911-916 r. Pedro María Vivaldo dejó establecido en 1649 que se le dieran 25 ducados de renta al año a la capilla de la Ascensión del convento de Santo Domingo, donde estaban enterrados sus padres y demás antepasados. 
ellos se fraguó en torno a 1584, pudiendo estar cimentada en torno a los negocios de Agustín Vivaldo con el librero Blas de Robles, del que fue apoderado, quien a su vez era gran amigo y paisano de Cervantes ${ }^{21}$. Este último compartía con Adán Vivaldo su pasión por la poesía, y de hecho en el libro VI de La Galatea introdujo un largo poema de su amigo titulado Canto de Caliope. Las finanzas fueron otra cuestión que les unió en determinados momentos, pues uno operaba como banquero y el otro como recaudador de impuestos. En 1597, estando ambos asentados en Sevilla, Cervantes fue encarcelado por problemas económicos, siendo posiblemente aliviados en parte con la ayuda de Adán. No es de extrañar que esto fuera la motivación para que el autor le incluyera también en dos capítulos de su obra El ingenioso hidalgo don Quijote de La Mancha, donde le cita como un gentilhombre que viaja de Toledo a Sevilla ${ }^{22}$.

\section{Las actividades económicas}

Las actividades mercantiles y financieras fueron desempeñadas por la familia Vivaldo desde muy temprano. El primer testimonio que disponemos data de 1238, momento en el que Vivaldo de Calignano, propietario de naves y financiero de empresas de armamento, importaba mercancias de las colonias genovesas de los mares Negro y Azov, las cuales posteriormente las colocaba en Cerdeña mediante hipoteca y préstamo ${ }^{23}$. En la península ibérica, a pesar del impedimento que tenían los extranjeros para comerciar en los distintos reinos peninsulares, lo practicaron, como ya hemos señalado, a finales de esa centuria los hermanos Bonavía, Pagán y Jácome. La restricción fue solventada por diferentes procedimientos: asociándose con un nativo; naturalizándose por medio del matrimonio; a través de concesiones reales emanadas de servicios monetarios prestados previamente; e incluso, por mediación papal. Los Vivaldo utilizaron todos estos artificios en determinados momentos, al menos así lo avala la documentación consultada. Un ejemplo del primero lo tenemos en Adán Vivaldo, quien se asoció con el jurado Hernán Vázquez para llevar mercancías y esclavos a isla de La Española ${ }^{24}$. Del segundo tenemos constancia por el matrimonio del citado Adán con Isabel de Ayala o el de Agustín Vivaldo con Francisca de Quintanilla ${ }^{25}$. En cuanto al beneplácito real, posiblemente el primero fuera como consecuencia del empréstito entregado a los Reyes Católicos por Agustín Vivaldo y sus socios Francisco Grimaldo y Nicolás Lomellini. Este serviría para sufragar parte de las 200.000 coronas de oro de la dote de su hija Catalina cuando se casó con el príncipe Arturo y, tras el

${ }^{21}$ AVALLE-ARCE, J. B.: Un banquero sevillano, poeta y amigo de Cervantes, Biblioteca Nacional, sig. CERVC/32/4.

${ }^{22}$ Ibid. Los capitulos en los que menciona a Adán Vivaldo en El ingenioso hidalgo don Quijote de La Mancha son el XIII (Donde se da fin al cuento de la pastora Marcela, con otros sucesos), y el XIV (Donde se ponen los versos desesperados del difunto pastor, con otros no esperados sucesos).

${ }^{23}$ VITALE, Vito: Vita e comercio nei notai genovesi dei secolo XII e XIII, Genova, Nella sede della Società Ligure di storia patricia palazzo Rosso, 1949, p. 52.

${ }^{24}$ Archivo General de Indias (AGI), Indiferente, 420, L. 9, f. ${ }^{\circ} 174 \mathrm{~V}$ (2).

25 AGI, Contratación, 5.314, N. 1, R. 48; 5.317, N. 1, R. 25; 5.318, N. 2, R. 25. 
fallecimiento de este, con su hermano Enrique VIII ${ }^{26}$. Por último, el relativo a la mediación papal queda patente en una carta de Julio II, fechada en Bolonia el 2 de diciembre de 1506, dirigida al arzobispo de Toledo fray Francisco Jiménez de Cisneros, en la que recomienda a los mercaderes genoveses Agustín Grimaldo y Agustín Vivaldo ${ }^{27}$. Resulta significativo que un año antes condecorara el pontífice a Stefano Vivaldo con la rosa de oro, honor que solo se otorgaba a las cabezas coronadas y a preeminentes personalidades, lo que demuestra el peso de esta familia en la curia romana. Este encargo estaría relacionado con el breve que dictó el papa en el mes de marzo de ese año en el que adjudicaba a la Santa Sede todos los expolios de los obispados de España, los cuales los recaudaría el nuncio Juan Ruffo, expidiéndolos los susodichos a Roma ${ }^{28}$.

La estructura de la compañia de los Vivaldo era similar a la de sus compatriotas ligures. La sede central, por lo general, se hallaba en Génova, donde el paterfamilias, habitualmente la persona de más edad, controlaba los bienes y coordinaba las relaciones con las sucursales foráneas donde se establecian algunos miembros de la casa, los cuales tenían amplia libertad de acción en la administración de esta. Cuando había más de un integrante se repartían las actividades (uno podía encargarse de los libros contables y el otro del numerario), aunque estas funciones las solian desarrollar una o dos personas contratadas para tal efecto, que a su vez eran asistidas por los oficiales de la pluma y los mancebos. Las sucursales no solo actuaban como agentes de la propia familia, también lo hacian para otras compañias, especialmente las de sus paisanos genoveses, dado que al estar fuera de su tierra natal los vínculos se tornaban más estrechos por ser el referente más cercano que tenían de ella.

Dentro de las actividades económicas, las operaciones de servicios y gestiones financieras fueron permanentes en el tiempo, especialmente las realizadas con la Iglesia y la Corona, lo que les facilitó acceder al comercio de esclavos y a las factorias de galeras. Los Vivaldo, a la par que efectuaban estos negocios realizaban transacciones con productos de toda indole, desde la compraventa de paños, lanas, papel y trigo, a la importación de azúcar, diamantes y perlas.

\subsection{Operaciones de servicios y gestiones financieras}

Las operaciones de este tipo fueron las actividades principales que la compañia Vivaldo realizó desde sus inicios, destacando la transferencia de numerario entre España y Roma. La remisión de capitales en su origen procedía de las rentas de los frutos eclesiales que la colecturía de España arrendaba desde 1479, las cuales - aunque habian quedado abolidas en el Concilio de Constanza de 1417- se siguieron percibiendo, lo que motivó las reiteradas quejas de Fernando el Católico, si bien no fueron tenidas en cuenta ${ }^{29}$. La magnitud

\footnotetext{
${ }^{26}$ FERNÁNDEZ NAVARRETE, Martín, Miguel SALVA y Pedro SAINZ DE BARANDA: Colección de documentos inéditos para la Historia de España, Imprenta de la viuda de Calero, tomo I, Madrid, 1842, pp. 356-366.

27 AHN, Universidades, Car. 1, N. 29.

${ }^{28}$ CARANDE, Ramón: "La gestión del nuncio Juan Poggio, colector general de la Cámara Apostólica en España", Boletín de la Real Academia de la Historia, tomo CLXXV, Madrid, 1978, pp. 503-504.

29 Ibid., pp. 495-533.
}

https:/ / doi.org/10.53335/cliocanarias.2021.3.10

Cliocanarias, ISSN 2695-4494, n. ${ }^{\circ} 3$ (2021), pp. 1-31, La Laguna (Canarias)/ 11 
del volumen movilizado posicionó a los miembros de esta familia como los segundos banqueros más importantes en expedir efectivos hacia Italia. Su momento más álgido fue en 1508, año en el que también iniciaron las remesas a Londres de la ya mencionada dote real. Estas actividades debían contar con un fuerte respaldo económico, de ahí que se asociasen con los Grimaldo, ya que estos poseían una potente casa cambiaria en dicha ciudad que se ocupaba, después de haber detraído los pertinentes descuentos, de entregar el importe a los tesoreros generales de la Cámara Apostólica ${ }^{30}$. Con el tiempo la sociedad se disolvió, haciéndose cargo los Vivaldo en solitario de la tesorería de la Cámara Apostólica en España ${ }^{31}$.

Las operaciones firmadas en Madrid eran suscritas por los parientes de Roma y también por los Lomellini, cuyos enfrentamientos judiciales sobrevenidos por discrepancias en los cambios efectuados en otros negocios no supusieron un freno para actuar conjuntamente en otras transacciones. Uno de los contenciosos más importantes fue el llevado a cabo en Génova en 1512 entre Agustín Vivaldo y Pantaleón Lomellini por ciertas remesas entregadas por el Gran Capitán, que posiblemente estuvieran relacionadas con las de Londres ${ }^{32}$. La relevancia de esta familia en las operaciones crediticias en la corte papal se incrementó en 1647 cuando fue nombrado Giovanni Girolamo Lomellini tesorero general de la Cámara Apostólica Romana ${ }^{33}$. Esto se extrapoló también a la Corte madrileña, donde a mediados de la segunda centuria del siglo XVII Ambrosio Lomellini y su compatriota Domingo Grillo se constituyeron como tesoreros de la Santa Cruzada ${ }^{34}$. A ellos les transferiria Juan Bautista Cassani Vivaldo en 1658 una libranza de 3.619.021 maravedies ${ }^{35}$.

El cargo de tesorero, al mismo tiempo que daba prestigio y credibilidad a la casa que lo ostentaba, permitía disponer de ingentes cantidades de numerario procedentes de las citadas rentas de las sedes episcopales vacantes, de la gestión y traslado de las bulas de los obispados, de las dispensas matrimoniales requeridas por las parejas que por lazos consanguíneos no podian contraer matrimonio sin el permiso papal y de cualquier otra gracia concedida por él. Los ajustes de las tres últimas se realizaban en Madrid, encargándose los agentes en Roma de abonar los costes de las gestiones y de remitirlas. Estas

30 CARRETERO ZAMORA, Juan Manuel: "La Colectoría de España en el siglo XVI: los mecanismos de transferencia monetaria entre España y Roma (cambios y créditos)", Hispania, vol. LXXIII, n. ${ }^{\circ}$ 243, 2013, pp. 79-103.

${ }^{31}$ Sobre los tesoreros de la Cámara Apostólica véase GIANNINI, Massimo Carlo: Note sui tesorieri generali della Camera apostolica e sulle loro carriere tra XVI e XVII secolo, Ècole Française de Rome, 2005.

32 ARCV, Signatura: Registro de Ejecutorias, caja 277, 39.

33 Sobre Giovanni Girolamo Lomellini véase GIANNINI, Massimo Carlo: Dizionario Biografico degli Italiani, vol. 65, 2005.

${ }^{34}$ Sobre los genoveses Ambrosio Lomellino y Domingo Grillo véase SANZ AYÁN, Carmen: Los banqueros..., op. cit., pp. 316-320; GARCÍA MONTÓN, Alejandro: "Trayectorias individuales durante la quiebra del sistema hispano-genovés: Domingo Grillo (1617-1687)", en HERRERO SÁNCHEZ, Manuel (Coord.): Génova y la Monarquía Hispánica (1528-1713), Nella Sede della Società Ligure di Storia Patria, Vol. LI (CXXV), fasc. I, y FERNÁNDEZ DURÁN, Reyes: La Corona española y el tráfico de negros. Del monopolio al libre comercio, Editorial del Economista, Madrid, 2011, p. 26.

35 AHPNM, leg. 8.354, fols. $1.295-1.295 \mathrm{v} .^{\circ}$. 
actividades reportaban asimismo importantes beneficios, pues al interés señalado para los gastos de conducción había que sumar los obtenidos por los cambios de moneda y por las adehalas, compensaciones eco-nómicas otorgadas graciosamente. Los movimientos de capitales entre España e Italia permitieron a los genoveses, ante las necesidades monetarias de la mo-narquía hispánica, constituirse como los principales banqueros reales durante los siglos XVI y XVII, posición compartida en ciertos periodos con los alemanes y portugueses.

Las operaciones bancarias con la Corona se iniciaron con las ya mencionadas remesas de la dote, siendo el siguiente empréstito conocido el de 1573, cuando Juan Pedro Vivaldo firmó un asiento con aquella, cuyas consignaciones le fueron abonadas a través de un privilegio sobre las rentas de la sal de Avilés $^{36}$. En 1594, tras un asiento de 300.000 ducados concertado con Felipe II, Agustín Vivaldo obtuvo una licencia para fundar un banco en Sevilla junto a su socio Pedro de la Torre Espinosa. Según Avalle-Arce el monopolio de la banca sería por diez años, aunque desconocemos si fue ampliado posteriormente con algún otro servicio real. En torno a mediados del siglo XVII Pedro María Vivaldo entregó a Felipe IV 23.800.000 maravedíes, trece millones de los cuales le fueron devueltos con la plata de Indias que se secuestró en 1649, el resto en el arca de tres llaves de la Tesorería General de Madrid ${ }^{37}$. Nueve años antes se había producido la revuelta catalana, por lo que para sofocarla Felipe IV tuvo que solicitar importantes sumas a los banqueros. Jerónimo Vivaldo aportó 120.000 reales de plata, que le fueron restituidos con una asignación anual de 9.000 reales de plata en los derechos del sello real de la secretaría de Nápoles ${ }^{38}$. Este no debió ser el único empréstito que firmó, al menos eso parece desprenderse del privilegio regio firmado el 24 de mayo de 1654 por el secretario Antonio Carnero en el que se le otorgaba la excepción y libertad perpetua para una casa que poseía en la calle del Lobo de Madrid. Cesión que finalmente no fue dispensada por la Real Junta de Aposento por presentar dos salvedades importantes: la primera, que pagaba menos de lo que realmente le pertenecía, porque la casa se edificó sobre el sitio ocupado por tres; la segunda, que existía una orden que prohibía adjudicar ninguna excepción sin carga, aunque fuera otorgada a los hombres de negocios con pretextos por sus asientos, alegación que debió presentar Jerónimo ${ }^{39}$. Aunque no logró el citado privilegio en esta ocasión, sí obtuvo otros, como la concesión de la explotación de las almadrabas reales de Cer- deña ${ }^{40}$.

En cuanto a los dos últimos auxilios económicos realizados a la Hacienda Real, se produjeron en 1662 y 1666, siendo satisfechos por Juan Bautista

\footnotetext{
36 ARCV, Pergaminos, caja 24, 5. Véase también ULLOA, Modesto: La Hacienda Real de Castilla en el Reinado de Felipe II, Fundación Universitaria Española, 1977.

37 ÁLVAREZ NOGAL, Carlos: "Los banqueros...", op. cit., p. 301.

38 AHPNM, leg. 8.355, fols. 712-712v; leg. 9.351, fols. 206-207v y 347-348r; leg. 11.447, fols. 261-262r, 729-729v; leg. 11.454, fols. 172-172v y 771-771v.

39 AHN, Informes y Certificaciones del Consejo de la Cámara del Real Aposento, Libro 8, pp. 255-257r.

40 AHPNM, leg. 8.353, fols. 21-22v, año 1655; leg. 9.351, fols 347-348r; leg. 11.447, fols. 261262r, 729-729v.
} 
Cassani. El primero, por importe de 25.000 pesos de plata, lo realizó en compañia de Juan Bautista Crota, mientras que en el segundo, de 25.000 reales de plata, concurrió en solitario ${ }^{41}$. Todo lo anterior nos remarca la importancia de esta casa bancaría, a lo que se sumaban los numerosos juros concedidos en las dos últimas centurias, deuda consolidada de empréstitos reales ${ }^{42}$.

Paralelamente a estos préstamos concertó Juan Bautista Cassani con el Consejo de Italia una serie de operaciones de transferencia de numerario desde Nápoles, Sicilia y el Estado de Milán a Madrid. Una de ellas fue para remitir los 400.000 reales de vellón que el Consejo de Italia aportó para el enlace matrimonial de Carlos II y Maria Luisa de Orleans, ya que los nobles, las ciudades y las instituciones contribuyeron sufragando los gastos de la boda. El resto de las operaciones estaban relacionadas con la conducción del sueldo, pensiones y ayuda de costa de los oficiales, tesoreros, secretarios, regentes y presidentes de dicho consejo que cada territorio italiano debía abonar. En referencia a los últimos sabemos que firmaron asientos el conde de Castrillo, Garcia Avellaneda y Haro; el duque de Sanlúcar y de Medina de las Torres, Ramiro Felipe Núñez de Guzmán; el conde de Oropesa, Duarte Fernando Álvarez de Toledo Portugal Monroy y Ayala, y el duque de Alba, Antonio Álvarez de Toledo y Beaumont. El importe total consignado a los susodichos por el sueldo anual de casa de aposento, tratas, luminarias, propinas, ceras, ventana del Corpus, capones, etc., los entregaba Juan Bautista Cassani en doce pagas iguales después de devengar los pertinentes intereses, de aplicar los descuentos y demás gastos de conducción.

Los regentes Alonso de Zúñiga y Oca y el marqués de Torralba, Benito Trelles Villamil, junto a los secretarios de Nápoles y Sicilia, Íñigo y Antonio López de Zárate, padre e hijo, también le comisionaron para percibir sus respectivos sueldos. Estos últimos, aprovechando la recepción de ese dinero, solicitaron además que les remitiera las rentas que cobraban en dichos territorios sus familiares. Este tipo de gestión también la realizó Juan Bautista Cassani para miembros de la nobleza que tenían intereses en Italia, entre los más destacados el almirante de Castilla, Juan Gaspar Enríquez de Cabrera y Sandoval, que percibía los beneficios de sus estados del condado de Módica y las baronías del reino de Sicilia. Mencionemos también al VII marqués de Villafranca, Fadrique Álvarez de Toledo, en relación con los de sus estados napolitanos de Fernandina y Montalbán. Asimismo, los de la condesa de Cabra, Leonor de Moscoso y Rojas, que disfrutaba de los beneficios del protomedicato de Nápoles que le había concedido el rey por los servicios prestados por su primer marido, Gaspar de Haro y Avellaneda. A ellos añadiremos a la condesa de Oñate y Villamediana, Catalina Vélez de Guevara, que ingresaba una renta del oficio de correo mayor de Nápoles.

Al tiempo que entregaba las partidas señaladas precedentemente, se ocupó de hacer efectivas las letras que sus correspondientes de Nápoles, Próspero Parisani, Juan Silvio Lanceta y Carlos Van Aelts, le remitieron durante los

\footnotetext{
${ }^{41}$ SANZ AYÁN, Carmen: Los banqueros..., op. cit., pp. 334, 503 y 508.

42 AGS, sig. CME, 549, 14; 548, 43; 550, 35; 548, 35; 142, 77; 143, 52; 729, 35; 394,9; 411, 6; 289, 129: у 216, 46.
} 
años 1669 y 1670, las cuales fueron libradas a favor de la reina regente Mariana de Austria, aunque debían ser abonadas a quien estableciera el presidente de Hacienda, Lope de los Ríos. Casi todas fueron entregadas al asentista real Sebastián de Oleaga, encargado de proveer de plata y caballos a los presidios de Cataluña. Solo dos de ellas se abonarian a Juan Guzmán, tesorero general de la Junta de Armadas, y a Diego González, tesorero general del Consejo de Indias. El importe total transferido en este tiempo superaría los 2.500.000 reales de vellón.

En este apartado de operaciones de servicios y gestiones financieras incluimos además la venta de títulos nobiliarios y tramitación de mercedes reales que, por las penurias económicas de la monarquía, especialmente en el siglo XVII, se vio constreñida a conceder a particulares previas retribuciones económicas $^{43}$. Las relaciones que mantuvieron los Vivaldo con el personal de los distintos consejos, especialmente el de Italia, les permitió conocer de primera mano la disponibilidad de títulos vacantes y les abrió las puertas para actuar como agentes para aquellas personas interesadas en la obtención de algún privilegio. La primera venta que conocemos es de un marquesado en el reino de Italia que le fue traspasado a Juan Bautista Cassani en 1661 por Juan Agustín Van Querri, cuya certificación fue avalada por el secretario del Consejo de Italia, Íñigo López de Zárate. Tres años más tarde lo vendió al napolitano Fernando de Quiroga y Fajardo ${ }^{44}$. De mano de los testamentarios de la condesa de Cabra, Leonor de Moscoso y Rojas, recibió Juan Bautista Cassani dos títulos como pago de las deudas que tenía la difunta contraídas con él. El primero fue un condado, que lo vendió en 1698 al juez de los dacios del Estado de Milán, el doctor Juan Antonio Guilizoni; el segundo, un ducado, que lo liquidó en Juan Bata Valignani45.

En cuanto a las actuaciones como agente nos consta que en 1678 tramitó para el conde Carlos Borromeo la concesión del Toisón de Oro ${ }^{46}$. También despachó en 1689 un hábito de caballero de Santiago para el senador y tesorero general del cantón de Lucerna, el señor Dullicher ${ }^{47}$, mientras que para el hijo del embajador extraordinario de los cantones católicos, Carlos Francisco Mauricio de Beroldinghen, consiguió una compañía de ordenanzas ${ }^{48}$; y para Alfonso y Carlos Cassati, padre e hijo, cuando estuvieron desempeñando la embajada española en la Helvética, obtuvo dos cuestoratos del magistrado ordinario de Milán ${ }^{49}$. Las tramitaciones de estos privilegios conllevaban un importante desembolso económico, dado que además del importe de venta de la propia merced real habia que sumar los derechos de secretaria, los beneficios del agente encargado de la gestión y las propinas que se repartían para la feliz consecución del asunto.

\footnotetext{
43 BENIGNO, Francesco: La Sombra del Rey. Validos y lucha politica en la España del Siglo XVII, Alianza Editorial, Madrid, 1994, pp. 16 y 17.

44 AHPNM, leg. 8.357, sin foliar.

45 AHN, Estado, leg. 1.978.

46 BRAH, sig. 9/3642r., Papeles particulares. Misiva escrita al caballero José de Beroldinghen en julio de 1687.

47 AGS, Estado de Milán, leg. 3.410, fol. 145.

48 AGS, Estado de Milán, leg. 3.408, fol. 222.

49 BRAH, sig. 9/3642r., Papeles particulares.
} 


\subsection{Los asientos de esclavos}

En torno a la infraestructura de transferencias de numerario y de las operaciones crediticias surgieron otro tipos de negocios en los que los Vivaldo participaron activamente. Uno de ellos fue el del tráfico de esclavos. La escasez de mano de obra para explotar el ingente territorio de las Indias españolas obligó desde muy temprano a la introducción de esclavos africanos para paliar esta insuficiencia. La Corona debía autorizar el origen y el número que tenían que transportarse. En 1510 estableció que la Casa de Contratación, creada para regular el comercio y la navegación con América, sería la encargada de la tramitación, siendo el puerto de Sevilla el lugar de partida de las expediciones a las costas africanas para recoger los cautivos y trasladarlos al puerto americano donde señalaba el pertinente permiso. Existían dos tipos de concesiones reales: la licencia, autorización graciosa del monarca, y el asiento, contrato entre el rey y un particular o compañía. Según la documentación consultada, los Vivaldo entraron en este negocio siguiendo la primera. El 18 de agosto de 1518 el emperador Carlos V entregó licencia al flamenco Lorenzo de Gouvenot, su mayordomo mayor y gobernador de la ciudad italiana de Bressa, para introducir 4.000 esclavos y esclavas a la isla de La Española y Cuba50. Sin embargo, este permiso, a pesar de la prohibición de participar los extranjeros en los negocios con América, fue transferido a los genoveses Adán de Vivaldo y Tomás de Forne, que participaban de esa actividad comercial asociados con el español Hernán Vázquez.

Una vez obtenida la señalada licencia, el Consejo de Indias instó a las autoridades, tanto a las sevillanas como a las indianas, para que se les permitiera a los susodichos establecer un factor en los territorios americanos donde iban a ser introducidos los citados esclavos. Llegado el barco negrero al puerto de destino, este agente, que solo tenía permiso para dedicarse en exclusividad a este negocio, realizaba una exhaustiva inspección y solicitaba el pertinente permiso de las autoridades para el desembarque. A continuación anotaba la mercancía recibida en los libros de registro y después procedía a la venta. Adán Vivaldo y sus socios encargaron a Melchor Centurión que procediese con este cometido en La Española. No obstante, su repentino fallecimiento les constriñó a despachar a otra persona para que se ocupara de todos los papeles e importes que por orden de la justicia de la isla habian quedado depositados en la casa de Juan de Villoria y Lope de Verdeci. También se comisionó a Esteban Justiniani, quien no cumplió debidamente su labor, pues los oficiales de la Casa de Contratación, a petición de Agustín Vivaldo y Tomás de Forne,

50 CORTÉS LÓPEZ, José Luis: Esclavo y colono. Introducción y sociología de los negroafricanos en la América española del siglo XVI, Ediciones Universidad de Salamanca, 2004, pp. 27-44. La documentación consultada solo nos habla de las islas de La Española y Cuba. Sin embargo, este autor señala que su destino también fue Jamaica y San Juan. Asimismo apunta que debían ser recogidos de Guinea y de las otras partes que se acostumbraba, pero sin tener que llevarlos a la Casa de Contratación de Sevilla. Sobre el mercado de esclavos, véase también VILA VILAR, Enriqueta: Hispano-América y el comercio de esclavos. Los asientos portugueses, Consejo Superior de Investigaciones Científicas, 1977; y GARCÍA FUENTES, Lutgardo: «E1 tráfico de negros hacia América", en ANDRÉS-GALLEGO, José (dir.): Tres grandes cuestiones de la historia de Iberoamérica: ensayos y monografias. Derecho y justicia en la historia de Iberoamérica; Afroamérica, la tercera raiz; Impacto en América de la expulsión de los jesuitas, Fundación Mafre, 2005. 
le reclamaron los libros y escrituras para verificar las deudas que tenía contraídas con los mencionados y que no habian sido abonadas ${ }^{51}$. Del factor delegado para las negociaciones de la isla de Cuba no tenemos constancia documental, aunque cabe la posibilidad de que fuera un miembro de la casa Vivaldo, ya que existen referencias que sitúan en América a varios de ellos. Algunos se instalaron definitivamente alli y otros pasaron solo para negociar. En cuanto a los primeros, podemos citar a Nicolás de Vivaldo, que llegó a San Juan de Ulúa, donde fallecería en 1562. Asimismo, Francisco de Vivaldo, que se había naturalizado en la villa de Peñafiel, embarcó en 1592 junto a otros 198 hombres, mujeres y niños, que dirigidos por Francisco de Vides, gobernador y capitán general de las provincias de la Nueva Andalucía y Cumara, poblarian las nuevas tierras descubiertas de las islas de Trinidad, Granada y Tabasco. También Juan Bautista de Vivaldo, avecinado en Sevilla, viajó en 1594 a Perú, donde acogió en 1610 a su pariente madrileña María de Vivaldo, posiblemente para casarse con ella. En cuanto a los segundos, tenemos el caso de Agustín Vivaldo, hijo de Adán Vivaldo, que se trasladó a América en 1609 en calidad de mercader, por lo que el tiempo de su estancia debía ser limitado52.

El negocio de los esclavos resultaba muy lucrativo, pues en sus inicios el importe abonado por cada uno de ellos era de dos ducados, cantidad que con el tiempo fue incrementándose considerablemente. Los dividendos se disparaban por la facilidad para cometer fraude introduciendo más de los permitidos. De hecho, los oficiales de la Casa de Contratación investigaron a Esteban Centurión, vecino de Granada, que vendió sesenta y tres licencias de esclavos sin tener permiso para ello, aunque alegó que eran de los 4.000 de Agustín Vivaldo, que tras el fallecimiento de Adán había quedado al frente de la casa, y Hernán Vázquez, quienes probablemente le cedieron una parte de la licencia $^{53}$. Otra fue traspasada por el citado Agustín y Domingo de Forne a los alemanes Enrique Ynguer y Jerónimo Sayler, que les permitía comerciar con el resto de los esclavos que faltaban para completarla. No obstante, las autoridades les obligaron a presentar la información que acreditaba que realmente no habían sido llevados a los puertos señalados ${ }^{54}$. Todo apunta también que fuera vendida por los mencionados mercaderes la real cédula del 14 de abril de 1526 en la que se ordenaba a la Casa de Contratación de Sevilla y a los gobernadores y oficiales de las Indias dejar pasar a Juan Fernández de Castro para llevar 307 esclavos, de los 1.000 que tenía autorizados de los 4.000 del gobernador de Bresa 55 .

La muerte de Adán Vivaldo en torno a 1525 generó algunas disensiones entre su sucesor y los socios del difunto. En 1626 los oficiales de la Casa de Contratación ordenaron que de los bienes que llegaron de las Indias para Agustín Vivaldo, relativos a una negociación de esclavos, fueran abonados a

51 AGI, Indiferente, 420, L. 8, fols. 37v-38r, 93r-93v, 331v-332r; 420, L. 9, fols. 50r-51r, 51r$51 \mathrm{v}, 52 \mathrm{r}, 52 \mathrm{v}-53 \mathrm{r} ; 420$, L. 10, f. ${ }^{\circ} 119 \mathrm{v}$; 1.961, L. 3, fols. 243v-244.

52 AGI, Contratación, 5.314, N. 1, R. 48; 200, N. 2, R. 8; 5.235, N. 1, R. 59; 5.247, N.1, R. 29; 5.317, N. 1, R. 25.

53 AGI, Indiferente, 1.963, L. 7, fols. 176v-177.

54 AGI, Indiferente, 1.961, L. 3, fols. 111-112.

55 AGI, Indiferente, 420, L. 10, fols. $301 \mathrm{v} .^{\circ}-302 \mathrm{v} .^{\circ}$. 
Juan Odón, mercader genovés asentado en Lisboa, a Hernán Vázquez y Domingo de Forne. Con este último se enfrentaría judicialmente por otra importante partida de maravedíes que quedó embargada y depositada en la citada institución hasta 1631, en que fue solventado el contencioso, que resultó desfavorable para Agustín. No solo en esta transacción salió perjudicado, pues en febrero de 1626 los oficiales de la Casa solicitaron que, dando las oportunas fianzas, desembargasen los bienes del fallecido para que su compatriota Jácome Grimaldo cobrase de ellos una deuda que tenía pendiente ${ }^{56}$.

No tenemos constancia documental de hasta qué fecha estuvieron los Vivaldo negociando con esclavos. Es muy posible que en el siglo XVII lo hicieran a través de sus compatriotas Domingo Grillo y Ambrosio Lomellini, que se convirtieron entre 1662 y 1674 en asentistas de esclavos, con los que ya operaban en los asientos de las factorías de galeras cuando estos se convirtieron en tesoreros de la Santa Cruzada.

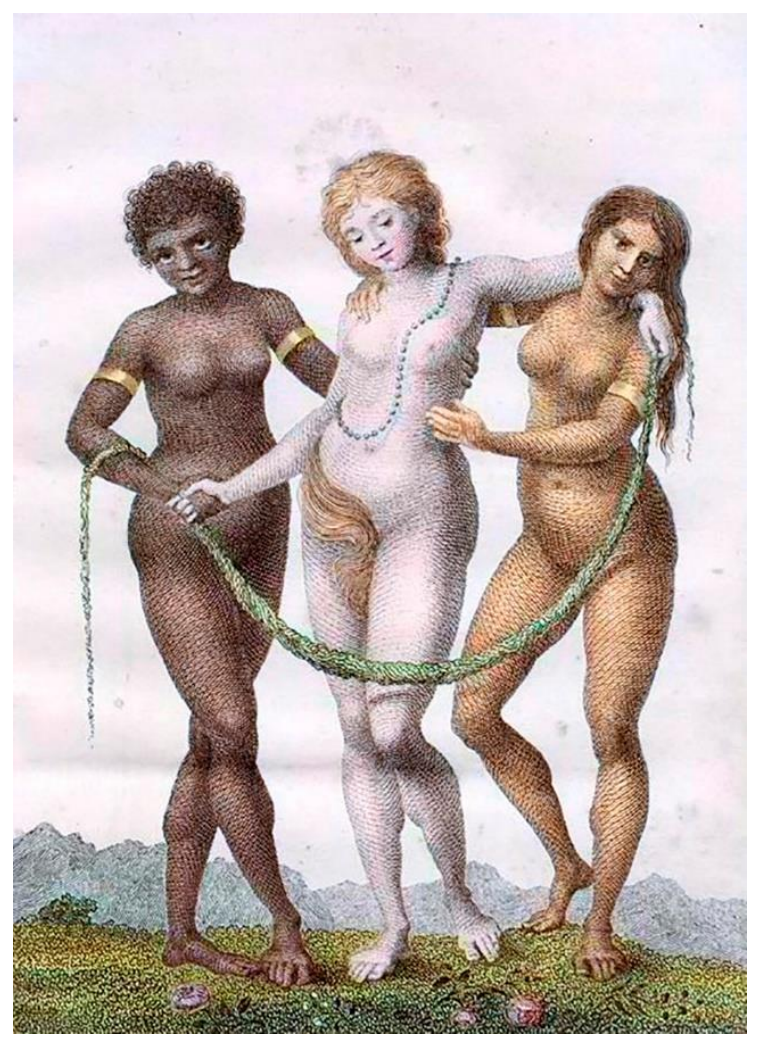

Figura 4. Europa sostenida por África y América. Grabado de William Blake (imagen de dominio público)

\subsection{Las factorías de galeras}

La Iglesia española asistía a la Hacienda Real con varios impuestos: las tercias reales, el excusado, el subsidio y la Cruzada. Los dos últimos eran destinados al sostenimiento de la guerra contra el infiel y a la construcción y suministro de las galeras. El rey pactaba con las autoridades eclesiásticas cada quinquenio la cantidad a aportar, elevándose hasta los 5.775.000 reales

56 AGI, Indiferente, 1.961, L. 2, f. ${ }^{\circ} .47 v^{\circ}$; L. 3, f. ${ }^{\circ} 119 \mathrm{r}-119 \mathrm{v}$; 420, L. 10, fols. 261v-262v.; y 421, L. 11 , fols. $176 \mathrm{v}-177 \mathrm{r}$. 
de vellón en los años comprendidos entre 1666 y 1670. Con el fin de sufragarla, la Iglesia y las órdenes militares españolas hacían un reparto de esa cantidad. Sin embargo, dicho importe no llegaba íntegro a las arcas reales, dado que externalizaban el cobro a los factores generales, a los que se les permitía obtener un porcentaje de los beneficios por los gastos de gestión y conducciones de capitales ${ }^{57}$. Los genoveses también intervinieron en este negocio, a los que el comisario general de la Santa Cruzada les despachaba la correspondiente libranza que les habilitaba para percibir los impuestos señalados, la cual solía ser traspasada a otros compatriotas. Una cuarta parte del importe debía hacerse efectivo en plata o en vellón con un premio del veinte por ciento; para el resto no se señalaba la forma, pero si subrayaba que debían realizarse los pagos en dos plazos, uno en el mes de junio y otro en diciembre.

La infraestructura montada en torno a la tesorería de la Cámara Apostólica, en cuanto a recogida de los beneficios eclesiales, favorecía a los Vivaldo para participar en esta actividad. De hecho, como ya hemos señalado, Juan Bautista Cassani cedió una libranza de 3.619.021 maravedies de plata en 1658 a Domingo Grillo y Ambrosio Lomellini, tesoreros generales de la Santa Cruzada ${ }^{58}$. Durante el quinquenio señalado al inicio de este apartado los factores de galeras y de la Armada real fueron Lorenzo Giustiniani y Juan Francisco Fiesco, quienes cedieron varias libranzas a Juan Bautista Cassani y Ansaldo Imperial, quien subrogó al anterior una de ellas. El primero, a través de sus agentes, cobró el subsidio y el arbitrio de la Santa Cruzada de las catedrales de Córdoba, Jaén, Sevilla, Cádiz, Cartagena, Orihuela, Sigüenza, Cuenca, Plasencia, Valencia, Segovia, Tuy, Orense, Mondoñedo, Santiago de Compostela, así como de la Casa de Contratación de Indias como receptora de los beneficios eclesiales procedentes de América; también, de las órdenes de Calatrava de la ciudad de Martos y la de Santiago de Ocaña. El importe total percibido fue de 1.853 .918 reales de vellón ${ }^{59}$.

Añádase que el Consejo Supremo de la Santa Cruzada depositó en Juan Bautista Cassani unas libranzas relativas a los años 1681 y 1682. Estas procedian del pleito surgido entre el duque de Tursi, Juan Andrea Doria Carreto, capitán general de la escuadra genovesa al servicio de las flotas de Carlos II, y los hermanos Juan Lucas y Eugenio Durazzo, quienes no se pusieron de acuerdo en el ajuste de cuentas sobre el sustento, sueldo y mantenimiento de dos galeras y una faluca. El importe total recaudado ascendió a 347.262 reales de vellón, que fueron aportados por las iglesias de Sigüenza, Osma, Valladolid, Toledo y Sevilla ${ }^{60}$.

Los beneficios obtenidos en estas operaciones serian incrementados con los percibidos en otras actividades comerciales en las que participaron desde los primeros tiempos de su llegada a España.

57 SANZ AYÁN, Carmen: Los banqueros..., op. cit., p. 175.

58 AHPNM, leg. 8.354, fols. 1295-1295v.

59 AHPNM, leg. 9.350, fols. 86-91v, 109-109v, 179-180r, 191-192r, 203-203r, 209-220r, 390395r, 407-407v, 408-408v, 537-537v, 695-696v; leg. 11.447, fols. 32-33v, 35-35v, 440-440v, 465-470v, 534-534v, 543-544r, 586-587r, 600-601r, 627-628r, 629-630r, 642-642v, 649662r, 789-789r, 793-794r y 825-826r.

60 AHPNM, Prot. 11.453, fols. 830-831r; Prot. 11.454, fols. 304-306r, 312-313r, 341-341v, $372-372 v, 386-386 v$ y $402-402 v$. 


\subsection{Transacciones mercantiles}

El mercado español, incrementado con el americano, facilitaba la participación en un amplio abanico de actividades mercantiles. Una de ellas fue el comercio de lanas, que durante la Baja Edad Media suscitó grandes conflictos entre los partidarios de la liberación de la exportación y los seguidores de las restricciones para surtir a los pañeros. Pese a que las leyes favorecieron a estos últimos, no evitó que la expediciones fueran progresivamente aumentando e incorporándose en este negocio los extranjeros, desplazando a los mercaderes castellanos, especialmente los burgaleses, riojanos, vascos y segovianos, que dominaron el mercado hasta finales del siglo XVI. A los problemas señalados habria que sumar en esta centuria la sublevación de los Países Bajos y las pésimas relaciones con Francia e Inglaterra. Esto conllevó que las exportaciones por los puertos de embarque del Cantábrico decayeran favoreciendo a los del Mediterráneo, que incrementaron las salidas hacia Italia, cuya demanda hasta ese momento fue de menor envergadura, centrada casi exclusivamente en las lanas sorianas ${ }^{61}$. Los Vivaldo fueron parte muy activa dentro de estas operaciones desde muy temprano. La documentación consultada señala en 1514 a Agustín comerciando con paños en Medina del Campo asociado con Cristóbal Calvo. Ambos se querellaron contra Juan de Ulloa, vecino de Toro, por el impago de esta mercancía. También en 1580 se seguiría un pleito por la misma causa ${ }^{62}$.

En cuanto a la exportación de lanas, se podía intervenir en todo o en parte del proceso: compra del vellón, transporte, venta en el exterior y financiación. Juan Bautista Cassani concurrió en todas las fases desde la década de los sesenta hasta mediados de los ochenta del siglo XVII junto a su compatriota Juan Bautista Monxardin, con quien formalizó una compañía que se encargaba de adquirir sacas de lanas en España y remitirlas a Génova, donde eran recibidas por José Monxardin, quien se las entregaba al comprador final, el principe de Galicano, Esteban Palavicino ${ }^{63}$. Durante este tiempo el negocio funcionó sin dificultad; sin embargo, las cincuenta y cuatro últimas sacas de añinos que expidieron en 1687 suscitaron una discrepancia entre los participantes al no ponerse de acuerdo en el precio. Para dirimir la diferencia se acudió al juez conservador de Juan Bautista Cassani, quien nombró a Andrés Squarzafigo y Centurión para que dictaminara el precio final, mientras que a José Romero se le ordenó que las sacas que estaban en depósito en Génova se las entregara al comprador, el citado príncipe de Galicano, pero debido al

61 DIAGO HERNANDO, Máximo: "Los mercaderes franceses en la exportación de lanas finas castellanas durante los siglos XVI y XVII. Una primera aproximación desde el escenario soriano", Hispania, vol. LXXII, n. ${ }^{\circ}$ 240, 2012, pp. 35-66; "Mercaderes italianos en Soria en los siglos XVI y XVII", Celtiberia, n. ${ }^{\circ} 107,2013$, pp. 195-242, e "Integración de los hombres de negocios genoveses en la sociedad madrileña del siglo XVII: El caso de los Sanguineto", Anales del Instituto de Estudios Madrileños, n. ${ }^{\circ}$ 54, 2014, pp. 89-122.

62 ARCV, Registro de Ejecutorias, caja 293, 5; caja 1.406, 21. También hace referencia al asentamiento de Agustín Vivaldo en Medina del Campo. Alonso García "De crédito y mercaderes: los circuitos financieros entre Castilla e Italia en los orígenes de la Monarquía Hispánica", Universidad Complutense, Madrid, 2005, p. 11.

63 AHPNM, leg. 11.454, fols. 239-239v. 
fallecimiento de este fueron adjudicadas a su única heredera, la duquesa de Zagarola ${ }^{64}$.

Juan Bautista Cassani no solo participó en el mercado de las lanas castellanas con destino a Italia, también tomó parte en la expedición de las lanas de vicuña procedentes de América. Esta actividad la realizó en sociedad con el notario del Santo Oficio de Sevilla Juan Lessa Arpe, quien las recepcionaba en esta ciudad y las remitía a San Sebastián para que el francés Pedro Ribanegra, líder en el mercado de exportación de las lanas castellanas, las vendiera en Francia65.

Otra actividad en la que tomó parte esta familia fue en la venta de balas de papel blanco. La documentación nos señala en 1495 a Julián Vivaldo comerciando con él junto a su compatriota Marcos Cattaneo66. El suministro de papel a los mercaderes de libros debió estar presente a lo largo del tiempo, pues así parecen confirmarlo algunos documentos notariales en los que se les señala. Uno de ellos, como ya citamos al principio, fue el amigo de Cervantes, Blas de Robles. También aparecen en diversos protocolos el leonés Juan de Valdés y los madrileños Mateo de Bastida y Antonio Bendejo67.

En relación con la comercialización de productos agrícolas señalaremos que el aumento de las zonas agrarias desde siglo XV, como consecuencia del incremento de la población, no favorecieron un abaratamiento de los precios. Los cereales, y el trigo en particular, generaban importantes beneficios, lo que animó a los inversores a participar en este negocio ${ }^{68}$. Adán Vivaldo aprovechó el tirón de buenas cosechas que se produjeron a partir de 1612 para exportar trigo de zonas excedentarias, como Castilla y Andalucía, a zonas deficitarias, como el País Vasco. En 1519 remitió a San Sebastián, junto a su socio Esteban Centurión, un cargamento cuyo precio fue concertado con el conde de Osorno, Garcia Fernández Manrique. Pese a ser un producto regulado por la Hacienda Real, los fraudes en las transacciones fueron constantes. De hecho, a Adán Vivaldo lo denunció en 1514 el regidor de Madrid Pedro de Zapata, acusándole por la venta de una saca de 1.000 cahíces de pan por valor de 500 ducados de oro. En 1522 también fue imputado por el secretario real Luis de Lizarazo por la saca de 700 cahíces de trigo ${ }^{69}$.

En lo que respecta a la importación de azúcar, posiblemente fuera consecuencia del comercio de esclavos que realizaban en la misma isla de La Española. El flujo mercantil debió de ser significativo en vista de que disponían de su propia nao, que Adán y su socio Hernán Vázquez compraron al donostiarra Pedro de Laborda ${ }^{70}$. Los transportes marítimos les llevaron a los Vivaldo a ser suministradores de las embarcaciones, siendo Agustín maestre de raciones en

${ }^{64}$ AHPNM, leg. 13.547, fols. 217-218v.

65 AHPNM, leg. 11.447, fols. 61-62v. DIAGO HERNANDO, Máximo: "Los mercaderes franceses...", op. cit., p. 64.

66 BONO, J.: Los protocolos de la época del descubrimiento, Sevilla, 1986, escribanía de Bernal González de Vallecillo, oficio XV, doc. n. ${ }^{\circ} 26,1986$.

67 AHPNM leg. 8.355, fols. 931-933r; leg. 11.455, fol. 201-201v.; y leg. 11.448, fols. 13-14r

68 Véase LYNCH, John: Los Austrias 1516-1700, Crítica, 2003, pp. 136-152.

69 AGI, Indiferente, 1.092, n. ${ }^{\circ}$ 16; AGS, CRC, 61, 3; y 52,4.

70 AGI, Indiferente, 420, L. 9, f. ${ }^{\circ} 174 \mathrm{v}$ (2). 
1618, encargándose de la provisión y distribución de viveres para la tripulación de la nave capitana de Nueva España. Su cometido no fue cumplido plenamente a tenor de que se procedió judicialmente contra él por esta cuestión y por el impuesto de avería de ese año, seguro marítimo obligatorio para todo mercader que traficase con las Indias, del que dependia el Consulado, institución que aunaba a todos ellos ${ }^{71}$.

El comercio con América no estuvo exento de peligros. La pérdida de barcos por la piratería o por naufragios fueron amenazas latentes en todos los viajes. El no arribar a puerto una nave suponía un perjuicio económico muy grande. Para mitigar en parte el daño se recurria a la justicia, aunque los procesos judiciales eran largos y costosos. Juan Francisco Vivaldo, junto a otros comerciantes que tenían intereses en la nao San Medel y San Celedón, que naufragó viniendo de Nueva España, demandaron al maestre Juan Lubelza y a sus fiadores por las grandes pérdidas que sufrieron. El juicio celebrado en la audiencia de la Casa de Contratación les fue favorable a los mercaderes, pero el citado maestre en 1544 apeló al Consejo por estar en desacuerdo con la sentencia ${ }^{72}$. El tráfico marítimo con América practicado por la familia Vivaldo les posicionó en un lugar destacado dentro de las instituciones sevillanas. De hecho, en 1630 Bartolomé junto a su socio Bautista Di Negro se convirtieron en agentes mercantiles. Es más, algunos autores señalan a ambos como los banqueros españoles más importantes de su tiempo ${ }^{73}$.

Dentro de los productos de lujo con los que también operaron se encontraban los diamantes, los cuales tuvieron una demanda muy significativa desde la más remota antigüedad. Se cree que fue Alejandro Magno el que los introdujo en Europa desde la India, donde existía una gran concentración de minas. Todavía en el siglo XVI la ciudad hindú de Biznagar gozaba de un gran mercado, donde acudia un sinfin de mercaderes de todos los lugares del mundo para comerciar con ellos ${ }^{74}$. En ese mismo siglo la talla de diamantes se perfeccionó considerablemente, constituyéndose Ámsterdam y Amberes como las dos ciudades donde el corte de las piedras se realizaba con mayor precisión. Desde esta última los importará Juan Bautista Cassani. En un principio debió remitírselos su hermano Domingo Maria, quien se ocupó de la casa Vivaldo en esta ciudad, después lo harian Miguel Moens y Guillermo Poteau. Las cantidades importadas fueron significativas, ya que existe documentación de diversas partidas, alguna con más de setenta y cinco piezas de diferentes tamaños y colores. Además, Juan Bautista Cassani contaba en su casa con

\footnotetext{
${ }^{71}$ AGI, Indiferente, 434, L. 8, fols.17r-17v; Escribanía, 956.

72 AGI, Justicia, 747 , n. ${ }^{\circ} 1$.

73 GÓMEZ-MENOR FUENTES, José Carlos: "Mas notas sobre los Yepes", Toletum, boletín de la Real Academia de Bellas Artes y Ciencias Históricas de Toledo, n. ${ }^{\circ} 33,1996$, pp. 175-199. Su actuación como cesionario la hemos tomado de LAPEYRE, Henri: Una Familia de mercaderes. Los Ruiz, Valladolid, Editorial Server-Cuesta, 2008, p. 232, quien a su vez lo ha tomado de RUBIO, J. A.: La Fundación del Banco de Ámsterdam (1609) y la Banca de Sevilla, Moneda y Crédito, 1948, pp. 19-20; ÁLVAREZ NOGAL, Carlos: Los banqueros de..., op. cit., pp. 161 y 177. La información relativa a que Bartolomé Vivaldo está trabajando en Sevilla nos la proporciona también VILA VILAR, Enriqueta: Los Corzo y los Mañara: Tipos y Arquetipos del Mercader con Indias, Universidad de Sevilla, 2011, pp. 137 y 141.

${ }^{74}$ MARTÍNEZ DEL ROMERO, Antonio (Dir.): Historia Universal Antigua y Moderna, Madrid, 1843, p. 120.
} 
dos pesitos de quilates con la quilatadora y tabla, más otra quilatera para perlas y marfil, lo que refuerza más si cabe esta afirmación. También es reseñable que entre sus amistades más íntimas se hallaba un gran entendido en ellos, Domingo Damisa y Torres, que desempeñaba el cargo de ayuda de guardajoyas de la reina Mariana de Austria, al que recurriria en determinadas ocasiones para que tasara algunas joyas en las que se incrustaron ${ }^{75}$.

Cuando recibia los diamantes, Juan Bautista Cassani los vendía a los joyeros de plata y oro o los mandaba engastar en alhajas, si así se lo solicitaba algún comprador. El nuncio apostólico, cardenal Millini, le encargó dos sortijas con diamantes grandes, guarnecidas de otros de menor tamaño, más un pectoral con las mismas gemas y una esmeralda, siendo realizadas ambas hechuras por el platero Juan de Morales ${ }^{76}$. Este tipo de transacciones que efectuaba estaban sujetas al correspondiente gravamen de los administradores de la alcabala de diamantes. Con el gremio de los joyeros de Madrid Juan Bautista Cassani tuvo un doble vínculo mercantil, y al ya mencionado se sumaba el de rentista, pues al menos cinco de ellos, junto a un relojero y un antojero, habitaban en el edificio de la calle de Santiago que pertenecia al mayorazgo de su mujer ${ }^{77}$. También nos consta que comerciaba con perlas, aunque desconocemos su procedencia, si bien el mercado americano era uno de los más importantes. Lo que sí hemos podido constatar es que en el inventario realizado tras la muerte de Juan Bautista Cassani se contabilizaron algunos paquetes de granos de aljófar, pequeñas perlas irregulares y otras muchas sueltas, además de diversas que estaban engarzadas en ricas joyas.

Por último, nos queda especificar que entre las numerosas operaciones mercantiles que manejaron los miembros de la casa Vivaldo se encontraban las letras de cambio, que no solo servian como pago de los ajustes realizados, sino que también representaban un negocio en sí mismo, dado que se podía emplear como préstamo con garantía, para mantener el capital circulante, para colocar numerario a corto plazo y para transferir fondos de un país a otro. Esto suponía arañar más beneficios en los cambios de moneda, especialmente con las extranjeras, y en los protestos por falta de pago en el plazo señalado.

\section{La bancarrota}

La diversificación de los negocios que hemos venido señalando no estuvo exenta de problemas para los Vivaldo, pues en determinados momentos sobrevino algún que otro quebranto económico derivado de impagos de mercancías, de deudas de letras de cambios, de débitos de censos e incluso de transacciones y cambios realizados dentro y fuera de la península ibérica. Estas dificultades suscitadas en determinadas operaciones conllevaban una serie de gastos en contenciosos judiciales, cuyas pérdidas eran contrarrestadas con los beneficios de otras. Sin embargo, en 1684 la concatenación de una serie de circunstancias adversas desencadenadas en un contexto de crisis económica llevó a la compañía a la bancarrota.

\footnotetext{
75 AHN, Jesuitas, Libros 249 y 246, f. ${ }^{\circ} 146$.

76 AHN, Jesuitas, Libros 246, 248, 249, 293.

77 AHPNM, leg. 8.717, fols. 690r-964v.
} 
Los orígenes de la quiebra podríamos remontarlos al año 1667, cuando Juan Bautista Cassani accedió a la embajada de los Cantones Católicos en España. Su nombramiento fue fruto de la concesión de varios créditos de una fuerte cuantía, 50.000 doblones, los cuales no pudieron ser sufragados por las autoridades cantonales, lo que les obligó en 1680 a cederle la renta de un juro de la media anata de mercedes que les había concedido la Corona como pago de los regimientos que sirvieron en los ejércitos hispánicos. El rendimiento ascendía a 20.000 escudos de vellón al año, que le otorgaron hasta el pago completo del principal —en 1727 todavía no lo habían cubierto-, que después revertiría a sus legítimos titulares. No obstante, el mismo año de la donación el tesorero de la media anata de mercedes dejó de abonar los intereses correspondientes a dicho juro, lo cual supuso un fuerte menoscabo, que sería subsanado ocho años más tarde después de un dificultoso y combativo proceso judicial 78 .

Además, su cargo de diplomático requería una serie de gastos de representación que Juan Bautista Cassani realizó con gran suntuosidad, pues a los costes propios de ella añadió otros, siendo los más señalados la adquisición de una finca a las afueras de Madrid, que era conocida por los habitantes de la corte como la Casa-Puerta. En ella mandó construir un palacio de gran belleza, cuyas paredes fueron decoradas por artistas de la talla de Dionisio Mantuano y Andrés Smith, de las cuales nos quedan referencias por el cronista madrileño Mesoneros Romanos, que las contempló. Una de ellas es la que mostramos a continuación.

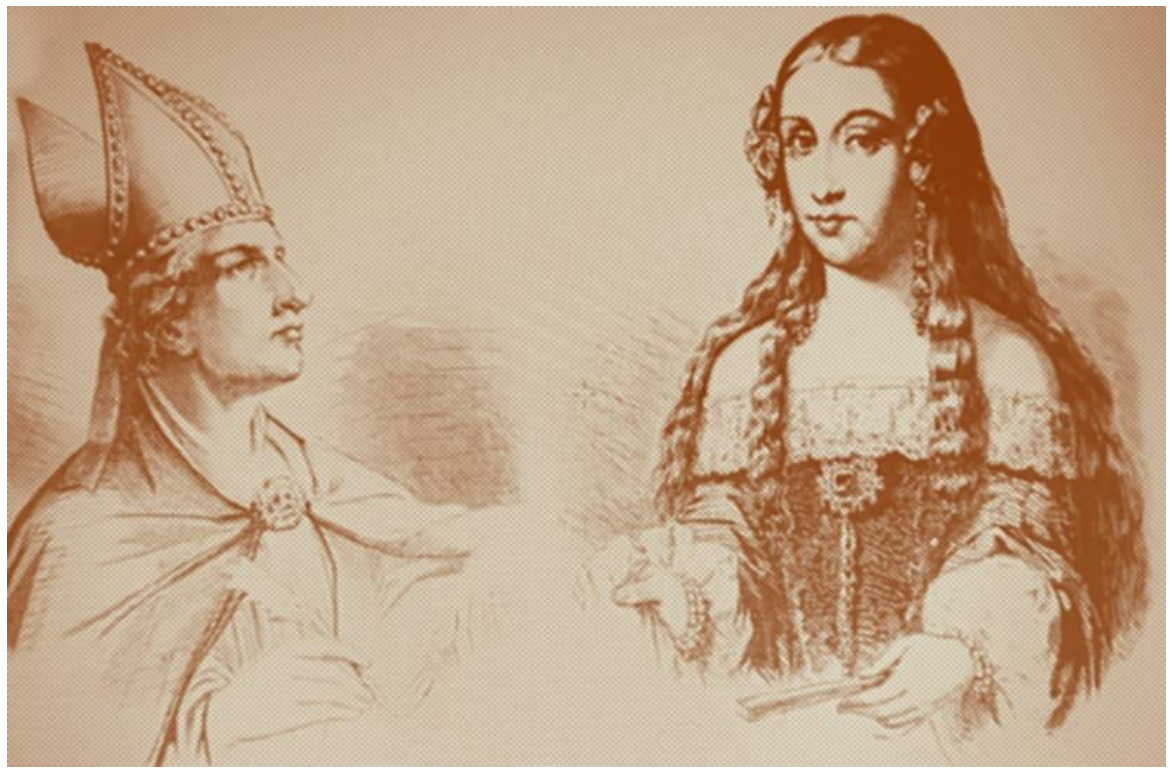

Figura 5. El obispo de Ávila Alfonso de Madrigal, el Tostado, y María Luisa de Orleans ${ }^{79}$

78 BRAH, Legajo Jesuitas, signatura, 9/7234. Sobre el desempeño del cargo de embajador, véase GÓMEZ OREÑA, Mercedes: "Los esguízaros en los conflictos bélicos de la Corona española. Una aproximación a la contratación y licenciamiento durante la embajada de Juan Bautista Cassani (1667-1704)", Revista de Historia Militar, n. ${ }^{\circ}$ 126, pp. 149-174.

79 MESONEROS ROMANOS, Ramón de: “El curioso Parlante”. Trabajos no coleccionados. Reformas de Madrid y de su Administración Amena Literatura", Hijos de M. G. Hernández, Madrid, 1903, pp. 364-372. 
Las delicias de su huerta y la hermosura de su jardín invitaban a grandes paseos a aquellas personas que la frecuentaban, entre los más asiduos el cardenal Millini, que siempre que disponía de tiempo la visitaba ${ }^{80}$.

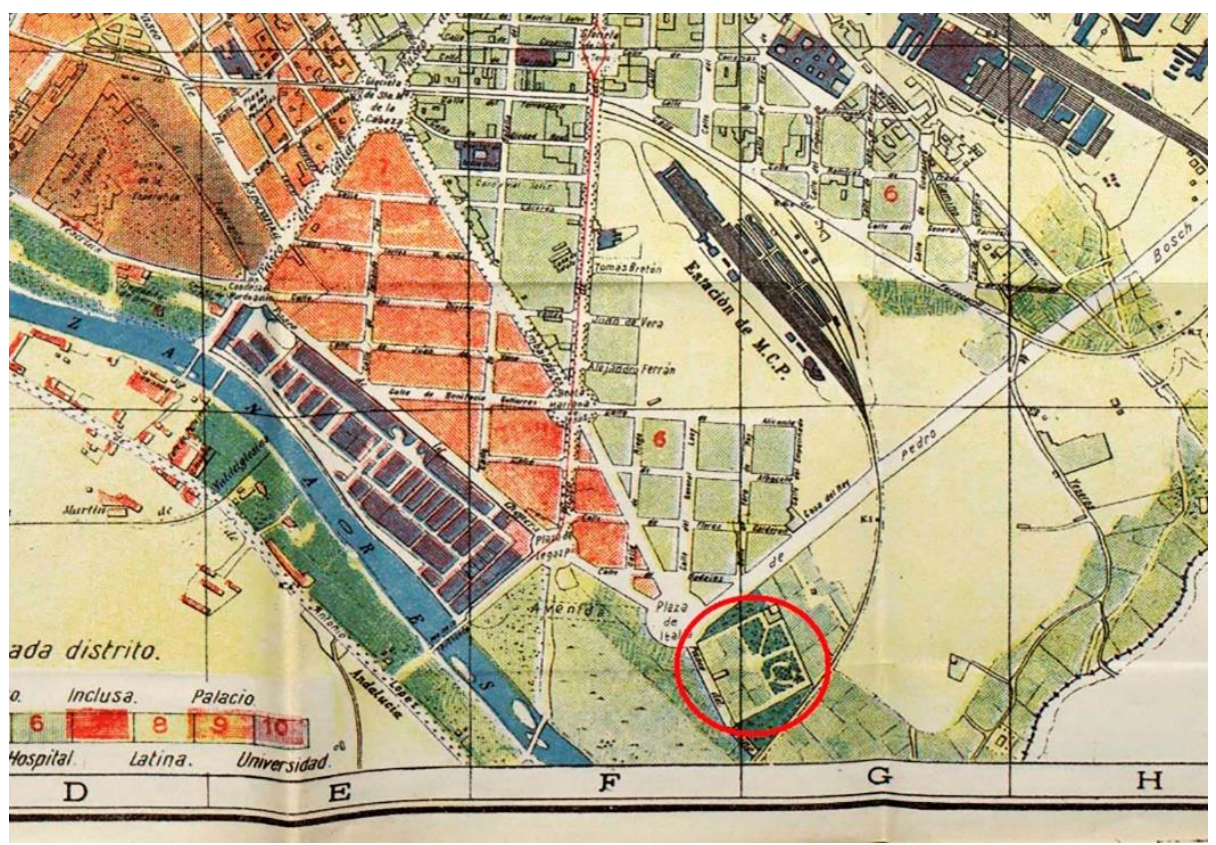

Figura 6. Plano "Noticiero-guía de Madrid" $1930^{81}$

También mandó reconstruir la casa en la que vivía de la calle del Lobo, a la que de igual manera dotó de grandes obras pictóricas, ricos muebles y suntuosos elementos decorativos. A esto había que sumar las elegantes vestimentas, las ricas joyas, los lujosos carruajes y un mayor personal al servicio de la familia.

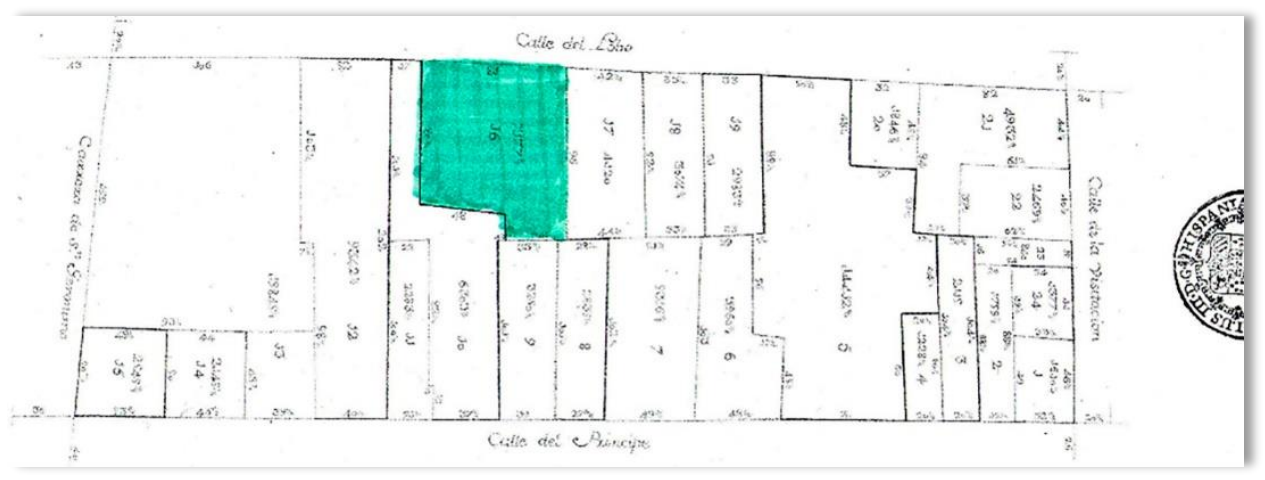

Figura 7. Solar de la vivienda de la calle del Lobo ${ }^{82}$

80 GARCÍA CUETO, David: Relaciones Artísticas entre España y Boloña durante el siglo XVII, tesis doctoral, Universidad de Granada, 2005, pp. 355-356, nota al pie 1.223.

${ }^{81}$ Este plano publicado al final del "Noticiero Guía de Madrid" de 1930 lo hemos consultado en la Biblioteca Regional de Madrid Joaquín Leguina. Dentro del círculo rojo aparece cómo estaba distribuida la finca. Para más información sobre ella, véase GÓMEZ OREÑA, Mercedes: "Nuevas aportaciones a la Historia de la Casa-Puerta. Una villa de estilo italiano en el Madrid del siglo XVII", Revista Destiempos, 61, pp. 13-46.

82 Fuente: Planimetría General de Madrid. El sombreado verde representa el solar ocupado por la vivienda, que en la citada planimetría viene señalado con el sitio 16, de la manzana 217. En la actualidad se corresponde con el número 8 de la calle Echegaray. 
El fuerte desembolso provocado por el acceso a la embajada fue seguido de una serie de imprevistos que se produjeron a partir de 1670 . Ese año se originó la quiebra del tesorero de la media anata de mercedes, Manuel de Perea, encargado de abonar los réditos del juro, que en esa fecha disfrutaban por completo los Cantones Católicos, siendo Juan Bautista Cassani, como su representante, encargado de percibirlos y remitírselos. Pese a no haber cobrado nada despachó a sus superiores los dividendos de su propio bolsillo. Incluso tuvo que hacer frente a los 400.000 reales de vellón que le habia prestado al citado administrador dos años antes y que tampoco le abonó. Contra él se formalizó un concurso de acreedores que retrasó en el tiempo el pago de la deu$\mathrm{da}^{83}$. Este hecho por sí solo no representaba una pérdida irreparable, ya que era contrarrestado con los ingresos de otras actividades económicas. Sin embargo, los graves problemas financieros que venía padeciendo la hacienda española obligaron a las autoridades en 1680 a tomar una serie de medidas, especialmente la depreciación de la moneda, que propició la bancarrota de las compañias que en ese momento estaban atravesando un momento de dificultad, arrastrando incluso a otras con cuentas saneadas.

La falta de liquidez de Juan Bautista Cassani en los primeros años de esa década fue resuelta con numerario que le prestaron sus compatriotas, el marqués de los Balbases, Pablo Spinola Doria, y el príncipe de Galicano, Esteban Palavicino; pero no fueron suficientes para capear el temporal, pues la Cámara Apostólica en ese momento le requirió el ajuste de los balances de los últimos diez años. Desconocemos si la citada institución conocia realmente la situación económica de Juan Bautista Cassani o detrás de esta decisión existían otros intereses ajenos a ella. Lo cierto es que al no poder liquidar en ese momento el montante adeudado se procedió judicialmente contra él, embargándole una serie de bienes, los cuales le serian devueltos dos años después de haberse resuelto el contencioso y haber satisfecho la deuda ${ }^{84}$. La pérdida de la tesorería no solo propició que muchos clientes abandonaran la confianza que habian puesto en su casa por el prestigio que esta les proporcionaba, sino que otros aprovecharon este momento de dificultad para demorar el pago de los créditos que habían contraído con él. Entre ellos se hallaba el VII duque de Alba, que le debía más de 479.000 reales de vellón, cuyo cobro resultó más complicado de lo esperado ${ }^{85}$.

A partir de 1684 a Juan Bautista Cassani se le retiró de la dirección de su compañia, pasando a ocupar su lugar el administrador impuesto por los acreedores, Andrés Squarzafigo y Centurión. No obstante, el estrecho vínculo entre los dos compatriotas propició que las disposiciones tomadas fueran consensuadas entre ambos, a veces en detrimento de los consignatarios. También fue favorecido por ostentar el cargo de embajador, que le supuso la concesión de un juez conservador o privativo para que su casa no fuera atropellada por los demandantes ${ }^{86}$. Esto no sería del agrado de alguno de ellos, especialmente de su agente romano Francisco Barlettani y de algunos de sus socios, que

83 AHPNM, leg., 11.447, fols. 183-187v.

84 AHPNM, leg. 11.455, fols. 78-80r.

85 AHN, Jesuitas, Libro 252.

${ }^{86}$ AGS, Estado de Milán, leg. 3.405 (46), fols. 189 y 205. 
gracias a la amistad con el nuncio de los Cantones Católicos, monseñor Cantelmo, pretendieron que este influyera en las autoridades suizas para que fuera destituido. Sin embargo, el importe que le adeudaban estas últimas a Juan Bautista Cassani era de tal magnitud que prefirieron mantenerlo en su puesto hasta su muerte, que se produjo en octubre de 1704. De igual forma influyeron en las decisiones las amistades que tenía en torno al Consejo de Italia, gracias a las cuales consiguió que la reina Mariana de Austria dirigiera dos cartas al gobernador del Estado de Milán, del que dependian las relaciones con ese territorio, para que intercediera por él ante las autoridades cantonales. Asimismo, mediaron por él el coronel De Beroldinghen, miembro destacado del partido proespañol en la Helvética, y el embajador de la Corona, el conde Carlos Casati 87.

\section{Conclusiones}

Los ascendentes de la saga Vivaldo en Génova estuvieron determinados por su trayectoria política y militar dentro de las instituciones de esa república y por sus incursiones mercantiles en el comercio con el oriente europeo. Por el contrario, el prestigio labrado en la península ibérica estuvo ligado a las operaciones financieras realizadas para la Cámara Apostólica, las cuales fueron posibilitadas por la notoriedad de uno de los miembros de esta saga, Stefano Vivaldo, durante el pontificado de Julio II. El traspaso de capitales entre España y Roma animó a la monarquía hispánica a utilizar también sus servicios de expedición y remisión de numerario de los territorios italianos. Esto supuso la base para otras actividades crediticias con la Corona, lo que les situó en un lugar más destacado de lo que se presuponía dentro del grupo de los banqueros reales genoveses. Estas dos instituciones les proporcionaban una distinguida reputación que les facilitaba la participación en negocios de otra índole, muchos de ellos a nivel internacional, como el comercio de esclavos y azúcar atravesando el océano Atlántico; la exportación de lanas por el Mediterráneo; la importación de diamantes desde el norte de Europa, o dentro del territorio peninsular con productos como el trigo, el papel y los paños. Algunas transacciones las realizaron en solitario, mientras que otras las gestionaron asociados con sus compatriotas.

Si el impulso que les permitió ascender dentro del mundo financiero fueron las transacciones con la Iglesia, también serian la causa de su caída, acaecida en 1684. Después de sufrir este percance, y a tenor de los bienes y débitos que se le adeudaban, pudo haber liquidado esta compañia y haber constituido una nueva, pues una quiebra comercial no tenía por qué implicar el abandono definitivo del entramado mercantil. Es más, muchos compatriotas suyos lo hicieron cuando se vieron en la misma tesitura. A decir verdad, Juan Bautista Cassani se planteó en un principio esta posibilidad, aunque pronto desistiria, pues apenas cuatro años después de haberse producido la bancarrota su hijo pequeño falleció, lo que le dejaba sin descendientes que le sucedieran en los negocios, dado que el único vástago que le quedaba había tomado la senda religiosa y se negó a abandonarla. Además, los más de cincuenta y cinco años que tenía Juan Bautista Cassani pesaban en su ánimo de iniciar una nueva

${ }^{87} \mathrm{BRAH}$, legajo 20 Jesuitas, sig. 9/3.642 
etapa. Tampoco su sobrino Mateo Ghirlandari Vivaldo, que se había desplazó a Madrid para ocuparse de los intereses de su padre, pudo constituir una nueva casa Vivaldo en Madrid al verse forzado a regresar a Roma en 1689 tras el deceso de su progenitor. Por último, su primo Carlos Vivaldo, que le asistió en los últimos momentos de su vida, tampoco pudo hacerlo, pues al trasladarse su hermano Giuseppe Maria de Sicilia a Cerdeña él tuvo que ocuparse de los intereses que dejaba en la primera isla.

Al menos, Juan Bautista no abandonó del todo las actividades mercantiles; de hecho, participó de forma continuada en las operaciones que el administrador concursal realizaba. Al mismo tiempo y de manera velada, gracias a su estatus de embajador, realizó algunas gestiones relativas a la concesión de privilegios reales. En 1704 se produjo su deceso, cesando la total actividad de esta saga de los Vivaldo en Madrid.

\section{Fondos documentales consultados}

-AGI: Archivo General de Indias.

-AGS: Archivo General de Simancas.

-AHN: Archivo Histórico Nacional.

-AHPNM: Archivo Histórico de Protocolos Notariales de Madrid.

-ARCV: Archivo de la Real Chancillería de Valladolid.

-BN: Biblioteca Nacional.

-BRAH: Biblioteca de la Real Academia de la Historia, Colección Salazar, sig. M-34, 50.761 (6) fol.29.

-BRMJL: Biblioteca Regional de Madrid Joaquín Leguina.

\section{Bibliografia}

ALONSO GARCÍA, D.: De crédito y mercaderes: los circuitos financieros entre Castilla e Italia en los origenes de la Monarquía Hispánica, Universidad Complutense, Madrid, 2005.

ÁLVAREZ NOGAL, C.: "Los banqueros de Felipe IV y los metales preciosos americanos (1621-1665)", Estudios de Historia Económica, 36, 1997.

- "Las Compañias Bancarias Genovesas en Madrid a comienzos del siglo XVII", Hispania, vol. 65, n. ${ }^{\circ}$ 219, 2005, pp. 67-90.

- El Crédito de la Monarquía Hispánica en el Reinado de Felipe IV, Ávila, Junta de Castilla León, 1997.

AVALLE-ARCE, J. B.: Un banquero sevillano, poeta y amigo de Cervantes, Biblioteca Nacional, CERVC/32/4.

BATTILANA, N.: Genealogie delle famiglie nobili di Genova, Dalla Tipografia dei Fratelli Pagano, Genova, 1825. 
BENIGNO, F.: La Sombra del Rey. Validos y lucha politica en la España del siglo XVII, Alianza Editorial, Madrid, 1994.

BONO, J.: Los protocolos de la época del descubrimiento, Sevilla, 1986, escribanía de Bernal González de Vallecillo, oficio XV, doc. n. ${ }^{\circ} 26$ (24-3-1495).

CARANDE, RAMÓN, "La gestión del nuncio Juan Poggio, colector general de la Cámara Apostólica en España", Boletín de la Real Academia de la Historia, tomo CLXXV, Madrid, 1978.

CARRETERO ZAMORA, J. M.: "La Colectoría de España en el siglo XVI: los mecanismos de transferencia monetaria entre España y Roma (cambios y créditos)", Hispania, vol. LXXIII, n. ${ }^{\circ}$ 243, 2013, pp. 79-103.

CORTÉS LÓPEZ, J. L.: Esclavo y colono. Introducción y sociología de los negroafricanos en la América española del siglo XVI, Ediciones Universidad de Salamanca, 2004.

DIAGO HERNANDO, M.: "Los mercaderes franceses en la exportación de lanas finas castellanas durante los siglos XVI y XVII. Una primera aproximación desde el escenario soriano", Hispania, vol. LXXII, n. ${ }^{\circ}$ 240, 2012, pp. 35-66.

- "Integración de los hombres de negocios genoveses en la sociedad madrileña del siglo XVII: El caso de los Sanguineto", Anales del Instituto de Estudios Madrileños, n. ${ }^{\circ}$ 54, 2014, pp. 89-122.

— "Mercaderes italianos en Soria en los siglos XVI y XVII", Celtiberia, Año n. ${ }^{\circ}$ 63, n. ${ }^{\circ}$ 107, 2013, pp. 195-242.

DÍAZ DE NORIEGA Y PUBUL, J.: La Blanca de la carne en Sevilla, Hidalguia, tomo I, II, y IV, Madrid, 1977.

DOMINICIS DE, C.: Membri del Senato della Roma Pontificia. Senatori, Conservatori, Caporioni e loro priori e lista d'oro delle famiglie dirigente (secc. $X$ XIX), Fondazione Marco Besso, Roma, 2009.

FERNÁNDEZ DURÁN, R.: La Corona española y el tráfico de negros. Del monopolio al libre comercio, Editorial del Economista, Madrid, 2011.

FERNÁNDEZ-MOTA DE CIFUENTES, M. T.: Relación de Titulos Nobiliarios Vacantes, y Principales Documentos que contiene cada expediente que, de los mismos, se conservan en el Archivo del Ministerio de Justicia, Instituto Salazar y Castro, Hidalguía, 2. ${ }^{\text {a }}$ edición, Madrid, 1984.

FERNÁNDEZ NAVARRETE, M., M. SALVA, y P. SAINZ DE BARANDA.: Colección de documentos inéditos para la Historia de España, Imprenta de la viuda de Calero, tomo I, Madrid, 1842.

GARCÍA CUETO, D.: Relaciones Artísticas entre España y Boloña durante el siglo XVII, Tesis doctoral, Universidad de Granada, 2005.

GARCÍA FUENTES, L.: "El tráfico de negros hacia América", en ANDRÉS-GALLEGO, J. (dir): Tres grandes cuestiones de la historia de Iberoamérica: ensayos y monografias. Derecho y justicia en la historia de Iberoamérica; Afroamérica, la tercera raíz; Impacto en América de la expulsión de los jesuitas, Fundación Mafre, 2005. 
GARCÍA MONTÓN, A.: "Trayectorias individuales durante la quiebra del sistema hispano-genovés: Domingo Grillo (1617-1687)", en HERRERO SÁNCHEZ, Manuel (Coord.): Génova y la Monarquía Hispánica (1528-1713), Nella Sede della Società Ligure di Storia Patria, vol. LI (CXXV), fasc. I.

GIANNINI, M. C.: Note sui tesorieri generali della Camera apostolica e sulle loro carriere tra XVI e XVII secolo, Ècole Française de Rome, 2005.

—Dizionario Biografico degli Italiani, vol. 65, 2005.

GILLIAM, M.: "La spedizione dei fratelli Vivaldo e nuovi documenti d'archivio", Atti della Società Ligure di Storia Patria, 1972, n. s. XVII, pp. 387-402

GÓMEZ-MENOR FUENTES, J. C.: "Mas notas sobre los Yepes", Toletum, boletín de la Real Academia de Bellas Artes y Ciencias Históricas de Toledo, n. ${ }^{\circ}$ 33, 1996, pp.175-199.

GÓMEZ OREÑA, M.: Juan Bautista Cassani. Un banquero genovés en la España del siglo XVII, Editorial Académica Española, 2018.

- "Nuevas aportaciones a la Historia de la Casa-Puerta. Una villa de estilo italiano en el Madrid del siglo XVII", Revista Destiempos, 61, pp. 13-46.

—Los esguízaros en los conflictos bélicos de la corona española. Una aproximación a la contratación y licenciamiento durante la embajada de Juan Bautista Cassani (1667-1704)", Revista de Historia Militar, n. ${ }^{\circ}$ 126, pp.149174.

GRENDI, E.: "Profilo storico degli alberghi genovesi", Mélanges de l'école française de Rome, 1975, 87-1, pp. 241-302.

HERRERO SÁNCHEZ, M.: Génova y la Monarquía Hispánica (1528-1713), Societá Ligure di Storia Patria, Génova, 2011.

— "La quiebra del sistema hispano genovés (1627-1700)", Hispania, n. ${ }^{\circ}$ 219, 2005.

JIMÉNEZ LÓPEZ DE EGUILETA, J. E.: "Micer Bonavía de Vivaldo, alcaide de El Puerto de Santa Maria, y los orígenes del latifundismo en la baja Andalucia (siglos XIII y XIV)", Revista de Historia de El Puerto, n. ${ }^{\circ}$ 60, 2018 (1 ${ }^{\mathrm{er}}$ semestre), pp. 133-147.

LAPEYRE, H.: Una Familia de Mercaderes: Los Ruiz, Editorial Server-Cuesta, Valladolid, 2008.

LYNCH, J.: Los Austrias 1516-1700, Critica, 2003.

MADAO, M.: Dissertazioni Storiche Apologetiche Critiche delle Sarde Antichità, nella Reale Stamperia, Cagliari, tomo I, 1792, pp. XXIII-XIV.

MARTÍNEZ DEL ROMERO, A. (Dir.): Historia Universal Antigua y Moderna, Madrid, 1843.

MESONEROS ROMANOS DE, R.: "El curioso Parlante». Trabajos no coleccionados. Reformas de Madrid y de su Administración Amena Literatura, editado por hijos de M. G. Hernández, t. I, Madrid, 1903.

MOGROBEJO, E., I. y G.: Diccionario Hispanoamericano de Heráldica, Onomástica y Genealogía, Editorial Mogrobejo-Zabala, Bilbao, 1995.

QUARTAPELLE, A.: "El "loco vuelo" de los hermanos Vivaldi en 1291", Revista de Historia Canaria, 200, 2018, pp. 227-249. 
RIVAROLA Y PINEDA DE, J. F. F.: Historia Chronológica y Genealógica, civil, politica, y militar de la Serenissima República de Génova, Diego Martín Abad, Madrid, 1929.

RUBIO, J. A.: La Fundación del Banco de Ámsterdam (1609) y la Banca de Sevilla, Moneda y Crédito, 1948.

SANZ AYÁN, C.: Los banqueros de Carlos II, Valladolid, Universidad de Valladolid, 1988.

-Un banquero en el siglo de Oro. Octavio Centurión, el financiero de los Austrias, La Esfera de los Libros, 2015.

ULLOA, M.: La Hacienda Real de Castilla en el Reinado de Felipe II, Fundación Universitaria Española, 1977.

VILA VILAR, E.: Hispano-América y el comercio de esclavos. Los asientos portugueses, Consejo Superior de Investigaciones Científicas, 1977.

-Los Corzo y los Mañara: Tipos y Arquetipos del Mercader con Indias, Universidad de Sevilla, 2011.

VITALE, V.: Vita e comercio nei notai genovesi dei secolo XII e XIII, Genova, Nella sede della Società Ligure di storia patricia palazzo Rosso, 1949. 